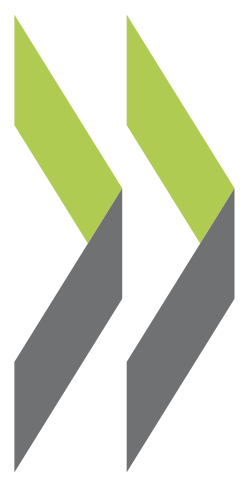

OECD Economics Department Working Papers No. 1247

Sustaining the economic expansion in New Zealand

Corinne Luu 
Organisation de Coopération et de Développement Économiques

Organisation for Economic Co-operation and Development

07-Jul-2015

ECONOMICS DEPARTMENT

English - Or. English

\section{SUSTAINING THE ECONOMIC EXPANSION IN NEW ZEALAND}

ECONOMICS DEPARTMENT WORKING PAPERS No. 1247

\section{By Corinne Luu}

OECD Working Papers should not be reported as representing the official views of the OECD or of its member countries. The opinions expressed and arguments employed are those of the author(s).

Authorised for publication by Robert Ford, Deputy Director, Country Studies Branch, Economics Department.

All Economics Department Working Papers are available at www.oecd.org/eco/workingpapers

JT03379898

Complete document available on OLIS in its original format

This document and any map included herein are without prejudice to the status of or sovereignty over any territory, to the delimitation of international frontiers and boundaries and to the name of any territory, city or area. 
OECD Working Papers should not be reported as representing the official views of the OECD or of its member countries. The opinions expressed and arguments employed are those of the author(s).

Working Papers describe preliminary results or research in progress by the author(s) and are published to stimulate discussion on a broad range of issues on which the OECD works.

Comments on Working Papers are welcomed, and may be sent to the Economics Department, OECD, 2 rue André-Pascal, 75775 Paris Cedex 16, France, or by e-mail to eco.contact@oecd.org.

All Economics Department Working Papers are available at www.oecd.org/eco/workingpapers.

This document and any map included herein are without prejudice to the status of or sovereignty over any territory, to the delimitation of international frontiers and boundaries and to the name of any territory, city or area.

The statistical data for Israel are supplied by and under the responsibility of the relevant Israeli authorities. The use of such data by the OECD is without prejudice to the status of the Golan Heights, East Jerusalem and Israeli settlements in the West Bank under the terms of international law.

\section{(C) OECD (2015)}

You can copy, download or print OECD content for your own use, and you can include excerpts from OECD publications, databases and multimedia products in your own documents, presentations, blogs, websites and teaching materials, provided that suitable acknowledgment of OECD as source and copyright owner is given. All requests for commercial use and translation rights should be submitted to rights@oecd.org 


\section{ABSTRACT/RÉSUMÉ}

\section{Sustaining the Economic Expansion in New Zealand}

The NZ economy has performed well over the past few years, having achieved relatively strong GDP and employment growth. However, some constraints to sustaining this momentum beyond the short term are emerging in the fields of skills, housing and urban infrastructure. Skills shortages have risen most in construction trades and management occupations. Housing shortages are most severe in Auckland, reflecting supply constraints in the face of population increases. As a result, prices are rising, reducing affordability. Urban infrastructure, particularly for road transportation, is also strained. In this respect, policy has a role to play in expanding economic capacity by reducing supply-side constraints and fostering productivity growth. At times New Zealand's fiscal policy has been expansionary during upturns. Ensuring that permanent spending or tax cuts are implemented in a sustainable manner would encourage the strong fiscal position that New Zealand needs to meet potentially large macroeconomic shocks and long-run ageing-related costs.

This Working Paper relates to the 2015 OECD Economic Review of New Zealand (www.oecd.org/newzealand/economic-survey-new-zealand.htm)

\section{JEL classification codes: E21, G28, H54, H6, J2, J61, R31, R4, R52}

Keywords: housing market, housing prices, fiscal councils, fiscal policy, immigration, infrastructure, labour market, land-use, macroprudential policy, New Zealand, saving, transport, urban planning

$* * * * * * * * * *$

\section{Pérenniser la croissance en Nouvelle-Zélande}

L'économie néo-zélandaise a enregistré de bons résultats durant ces dernières années, et le PIB tout comme l'emploi ont bénéficié de taux de croissance relativement élevés. Toutefois, cette dynamique pourrait être contrariée à moyen terme par plusieurs difficultés émergentes en matière de compétences, de logement et d'infrastructures urbaines. Les pénuries de compétences affectent principalement les métiers de la construction et les fonctions d'encadrement. Le déficit de logements est avant tout marqué à Auckland, en raison des contraintes pesant sur l'offre de logements et de l'accroissement démographique. Les prix sont donc tirés à la hausse tandis que les possibilités d'accéder au logement diminuent. Les infrastructures, notamment les réseaux routiers, présentent également des insuffisances. À cet égard, les politiques publiques peuvent contribuer à accroître les capacités économiques, en réduisant les contraintes sur le versant de l'offre, et en favorisant les gains de productivité. Par le passé, la Nouvelle-Zélande a suivi une politique budgétaire expansionniste durant certaines phases de reprise économique. Il convient de s'assurer de la viabilité financière à long terme de toute mesure entraînant des dépenses budgétaires ou fiscales permanentes, afin que la Nouvelle-Zélande se trouve dans une situation budgétaire solide lui permettant de faire face à d'éventuels chocs macroéconomiques d'importance et d'assumer, à plus long terme, les coûts liés au vieillissement de sa population.

Ce Document de travail se rapporte à l'Étude économique de l'OCDE de la Nouvelle-Zélande 2015 (www.oecd.org/fr/nouvellezelande/etude-economique-nouvelle-zelande.htm).

Classification JEL : E21, G28, H54, H6, J2, J61, R31, R4, R52

Mots clefs: marché du logement, prix des logements, conseil budgétaires, politique budgétaire, immigration, infrastructures, marché du travail, aménagement du territoire, politique macroprudentielle, Nouvelle-Zélande, épargne, transports, urbanisme 


\section{TABLE OF CONTENTS}

SUSTAINING THE ECONOMIC EXPANSION IN NEW ZEALAND ….....................................................

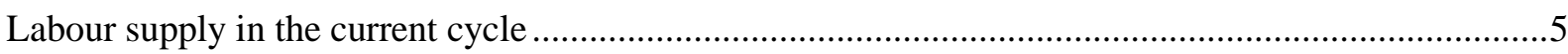

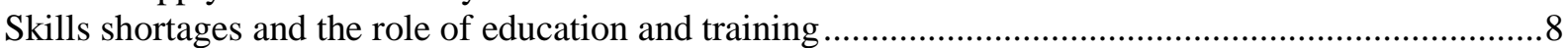

Migration and targeted initiatives have reduced skills shortages, particularly in Canterbury................12

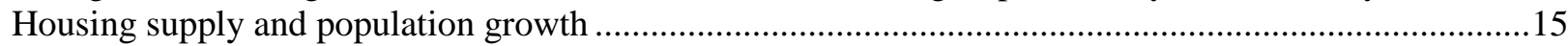

Supply responsiveness should continue to be targeted for improvement.............................................18

Increasing resources in the construction sector has tended to reduce labour productivity growth ........20

Continued attention to reducing housing risks is needed beyond encouraging supply .........................21

Providing infrastructure to support the economic expansion.................................................................23

Congestion and the variability of travel time remain an issue in large urban areas .............................26

Diversify infrastructure funding by making more use of user-based funding and land value capture...28

Demand management strategies could encourage a better use of existing infrastructure ......................29

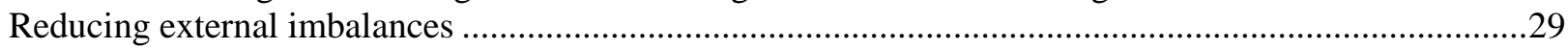

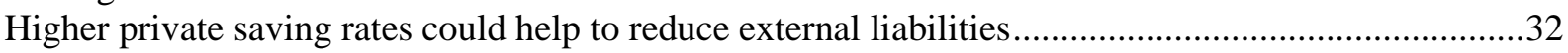

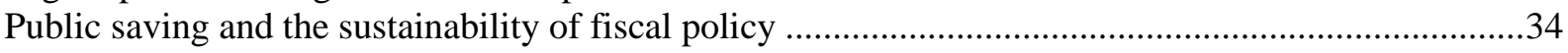

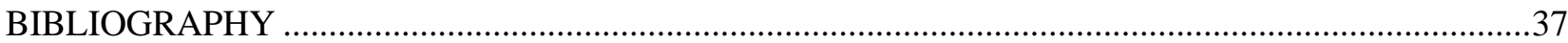

\section{Figures}

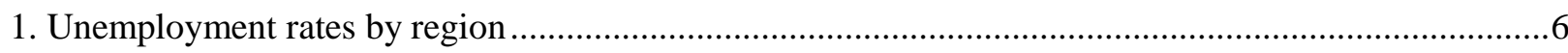

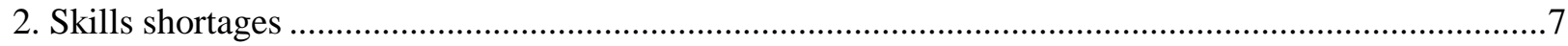

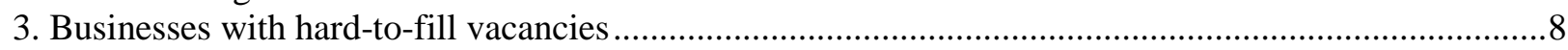

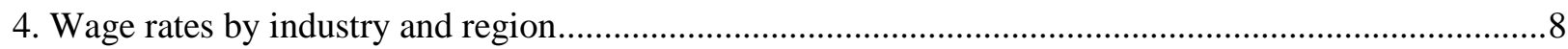

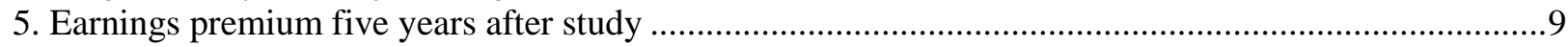

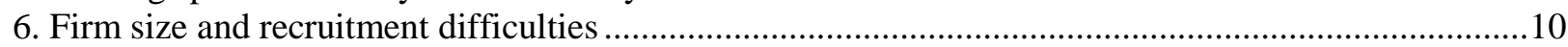

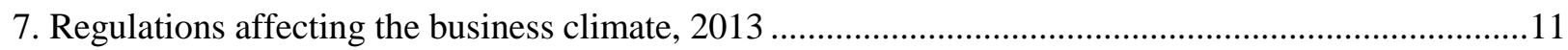

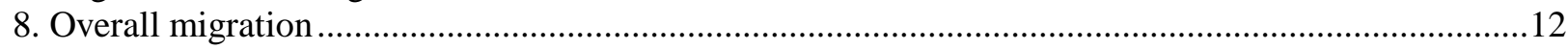

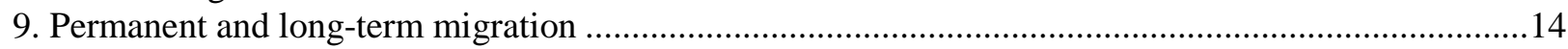

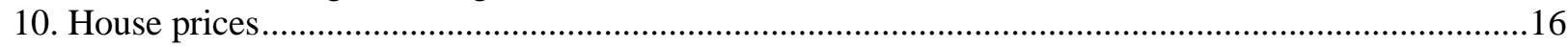

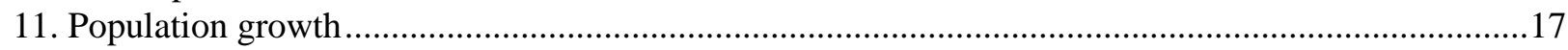

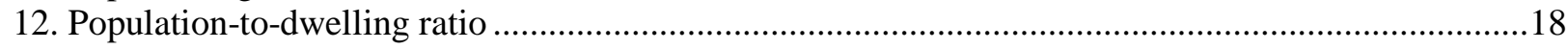

13. Burdens on the economy due to environmental policies and policy stringency ................................19

14. Firms are concerned about skilled labour and the quality of local planning and regulation................21

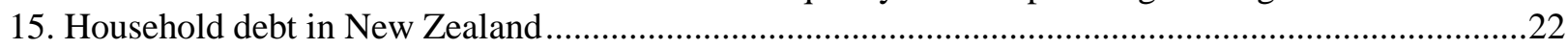

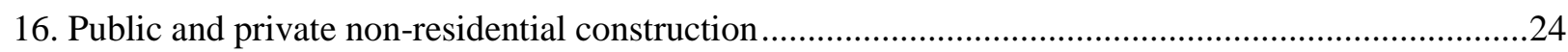

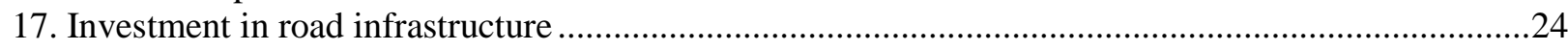

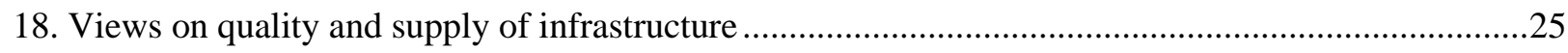

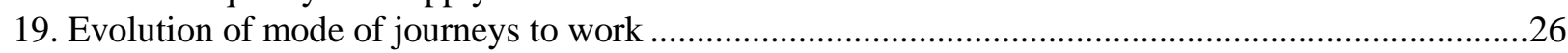

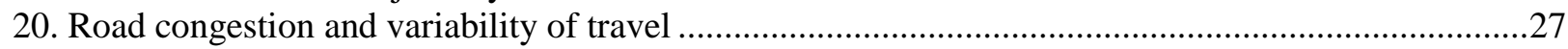

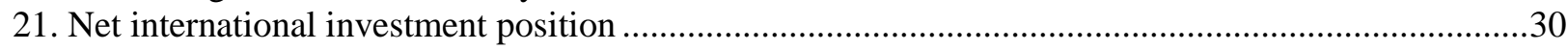

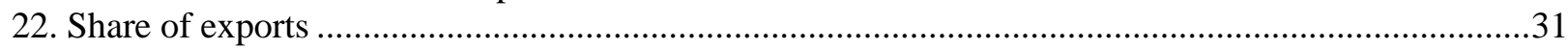

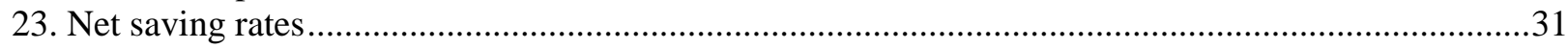

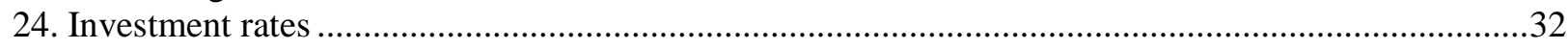

25. Real house prices and the dynamics of saving and current account balances...................................34 
ECO/WKP(2015)65

\title{
SUSTAINING THE ECONOMIC EXPANSION IN NEW ZEALAND
}

\author{
By Corinne Luu ${ }^{1}$
}

New Zealand has witnessed robust growth since 2011, buoyed in part by terms-of-trade gains, despite some recent reversal, and reconstruction activity related to the 2010-11 Canterbury earthquakes. Strong job creation has encouraged high net immigration, and unemployment rates have fallen. Constraints to sustaining strong growth in the NZ economy beyond the short term are emerging in skills, housing and infrastructure. Policy can play a role in enabling the economy to address these shortages and increase prospects for productivity gains. Risks associated with high house prices and heavy external debt remain, and measures to lessen these risks could also aid in increasing the durability and underlying pace of the expansion.

The analysis in this paper will: $i$ ) look at the extent to which labour supply has been responsive to demand, including the role of education and immigration in labour market adjustment, and whether skills shortages have emerged; $i$ i) review the responsiveness of housing supply to strong population growth and the related regulatory framework; iii) examine infrastructure bottlenecks and funding frameworks that could facilitate increased infrastructure provision and possible demand-management practices that could enable more efficient use; and iv) assess risks to the NZ economy, particularly related to external debt, which may cut short the expansion and policy measures to address these issues.

\section{Labour supply in the current cycle}

Employment has expanded rapidly since 2012, with widespread gains by sector. One industry that has stood out has been construction, where increased labour demand reflects reconstruction activity following the Canterbury earthquakes in 2010-11 and strong residential building in Auckland. As a result, the NZ labour market has tightened. National unemployment has trended down since late 2012 but remains above pre-recession outcomes (Figure 1). However, unemployment rates are near all-time lows in Canterbury, reflecting demand for construction-related workers, as well as service-sector positions to support rapid population growth.

1. Corinne Luu is an economist in the Country Studies Branch of the Economics Department of the OECD; e-mail: corinne.luu@oecd.org. This paper was prepared for the OECD Economic Survey of New Zealand published in June 2015 under the authority of the Economic and Development Review Committee. The author is thankful to Christophe André, Bert Brys, David Carey, Robert Ford, Stéphanie Guichard, Peter Jarrett, Tomasz Koźluk, Andrew McQueen, Stéphanie Payet, Alvaro Pereira and New Zealand government officials for their valuable comments and suggestions. Special thanks are due to Isabelle Duong for excellent statistical assistance and Mee-Lan Frank, Dacil Kurzweg and Krystel Rakotoarisoa for technical preparation. 


\section{Figure 1. Unemployment rates by region}

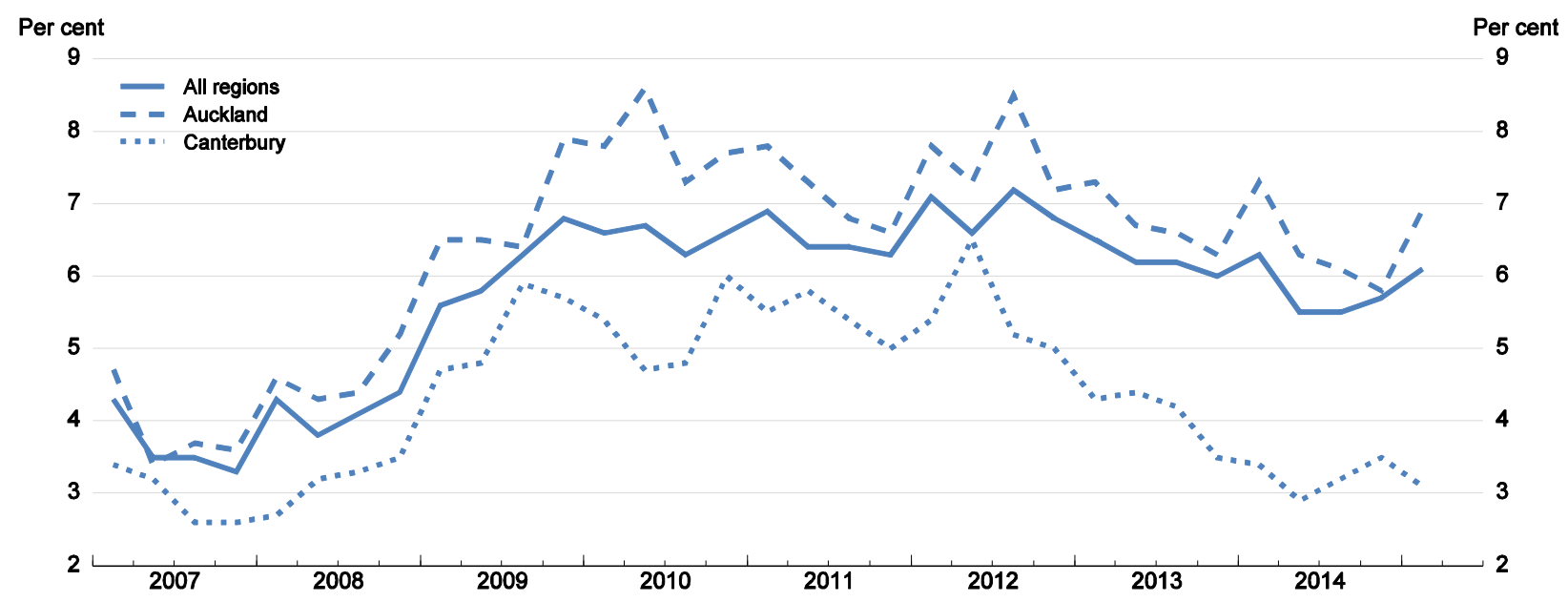

Source: Statistics New Zealand.

Along with rising demand for labour, skilled vacancies have trended up since late 2009. Based on online job-vacancy figures, increases in vacancies have been fairly broad based, with the largest increase in openings for technicians and trade workers (Figure 2, Panels A and B). However, such data may understate actual vacancies for industries where recruitment takes place outside of the two main online job boards (SEEK and TradeMe). For instance, in the information technology sector recruiters tend to use specialist online jobs boards and head hunters, which are excluded from the Jobs Online Index. In addition, skilled vacancies may understate the demands from the construction sector, given a high degree of self-employment and the industry's small scale. In any case, mirroring employment developments, skilled vacancies have risen the most in Canterbury, outpacing the national level since 2011 (Figure 2, Panel C).

According to the New Zealand Institute of Economic Research's (NZIER) Quarterly Survey of Business Opinion, skilled labour has become steadily more difficult to find, with a rising net number of firms reporting hiring difficulties since mid-2010, but labour appears to be easier to source than during the years leading up to the 2008-09 global recession. Although businesses report increased difficulties in hiring both skilled and unskilled labour across the country, shortages are most acute in Canterbury (MBIE, 2014a). Furthermore, Statistics New Zealand's Business Operations Survey (BOS) for 2014 showed that construction vacancies were some of the hardest to fill, although the degree of difficulty is less severe than in 2008 during the last construction cycle (Figure 3). 
Figure 2. Skills shortages

Index of skilled vacancies, trend series, January $2009=100$

\section{A. By industry}

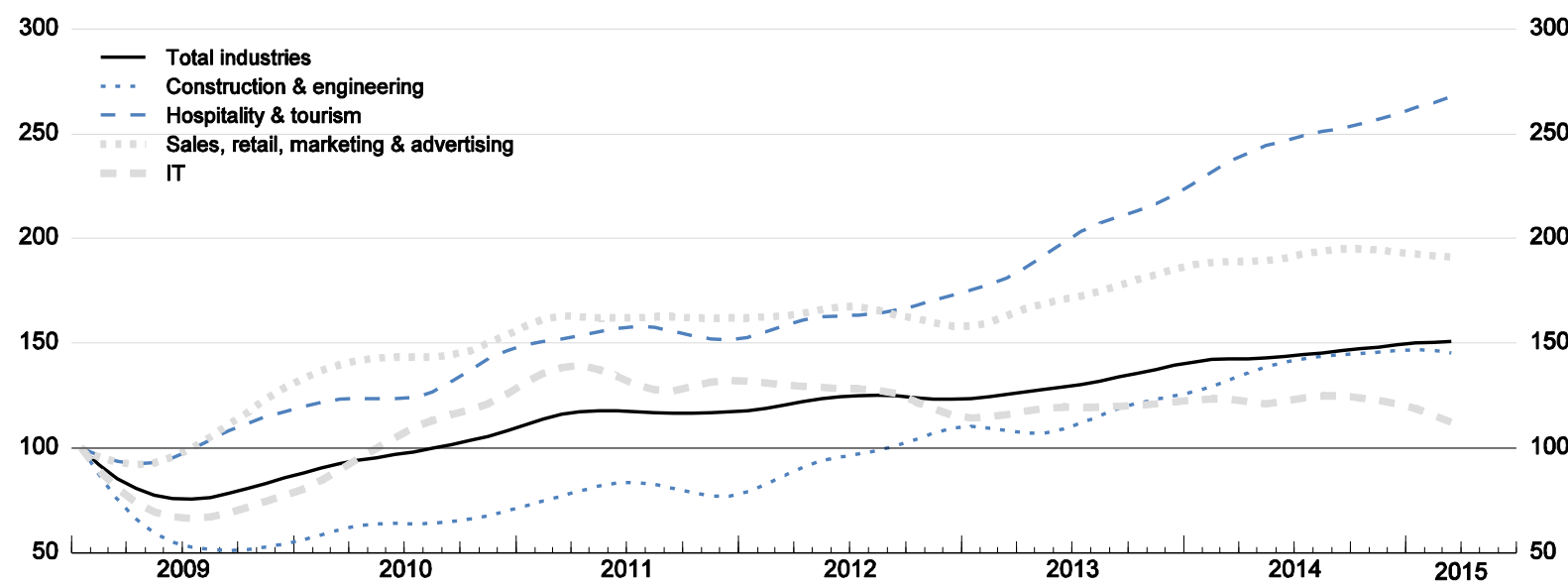

\section{B. By occupation}

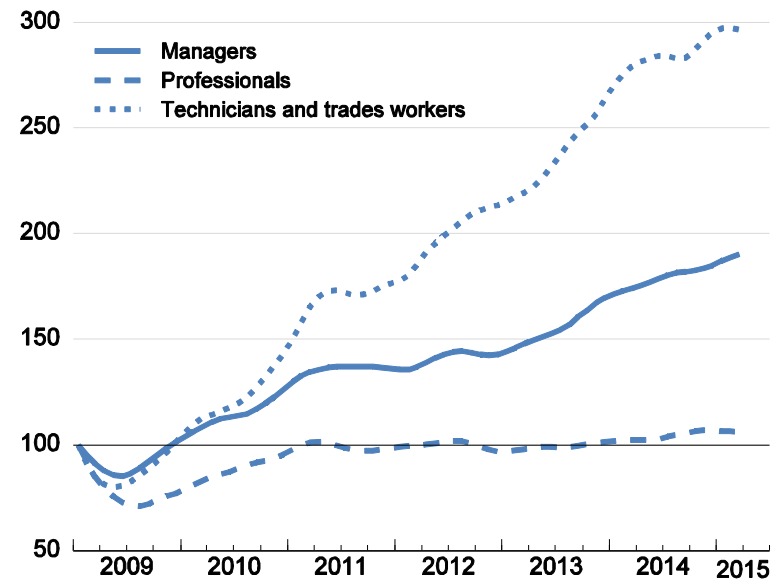

\section{By region}

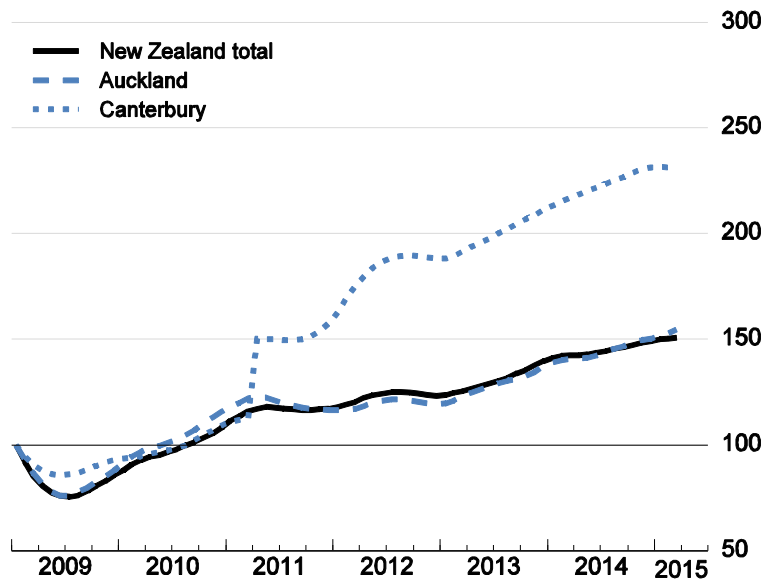

Source: Ministry of Business, Innovation \& Employment (2015), Jobs Online Monthly Report, March.

According to the conventional definition, skills shortages tend to occur when employers are unable to recruit staff with required skills at the going rate of pay. In order to attract more staff when facing a shortage, employers tend to offer increased wage rates for required skills, which eventually encourages individuals to acquire skills in high demand. This is consistent with results from the BOS: as a result of hard-to-fill vacancies, roughly $40 \%$ of respondents increased salaries and raised advertising and recruitment spending, and a third increased training and/or redefined existing jobs (Statistics New Zealand, 2014). Yet, despite widespread employment gains and rising vacancies, wage pressures have been fairly subdued. While stronger construction wage growth has occurred in Canterbury, aggregate construction wage growth (based on the labour cost index) does not appear to be significantly out of line with other industries (Figure 4). A similar lack of wage pressures from the construction sector was also witnessed during the last construction boom in 2000-09 (Department of Labour, 2011). This suggests that, despite tightening labour markets, both skilled and general labour shortages appear to have been fairly well contained. 
Figure 3. Businesses with hard-to-fill vacancies

Last financial year at August 2008 and $2014^{1}$

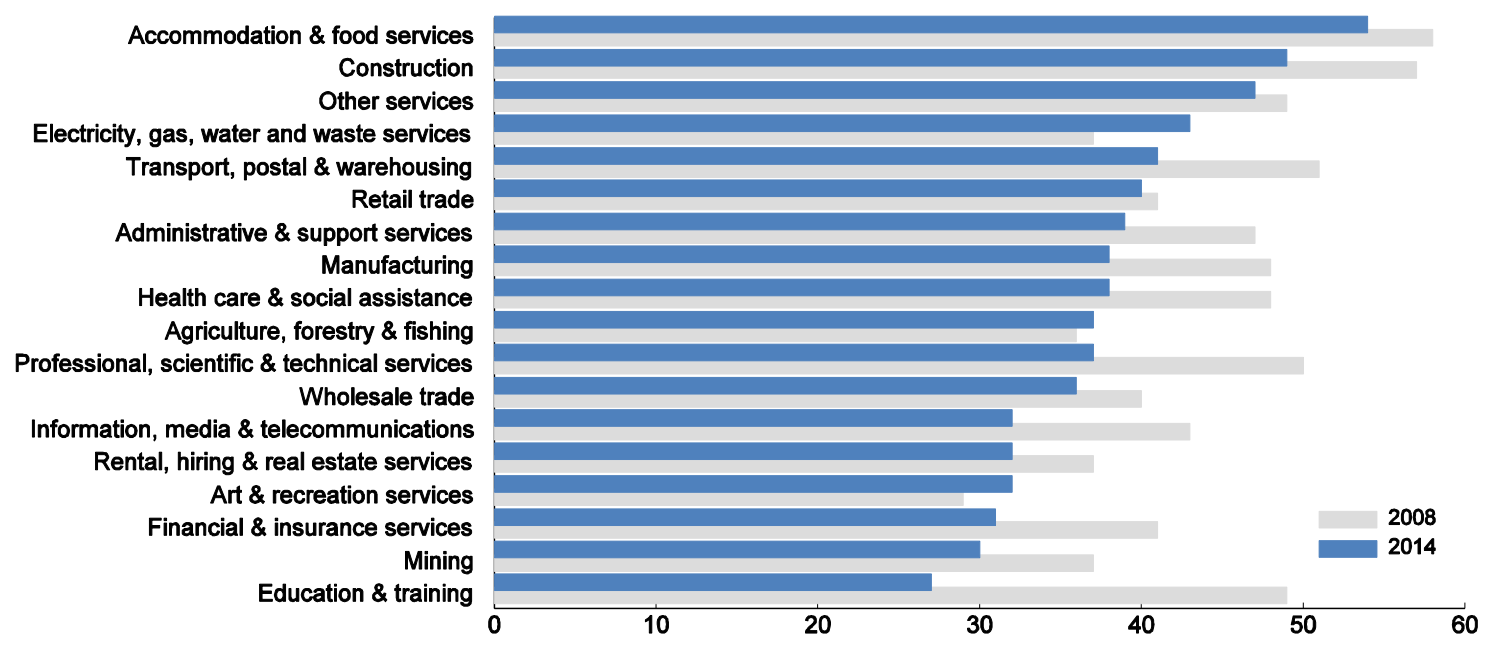

1. Last financial year refers to the last financial year for which businesses had results available in August. Financial years for businesses finish on 31 March in New Zealand.

Source: Statistics New Zealand, Business Operations Survey: 2013 and Business Operations Survey: 2014.

Figure 4 . Wage rates ${ }^{1}$ by industry and region

Year-on-year percentage growth rate

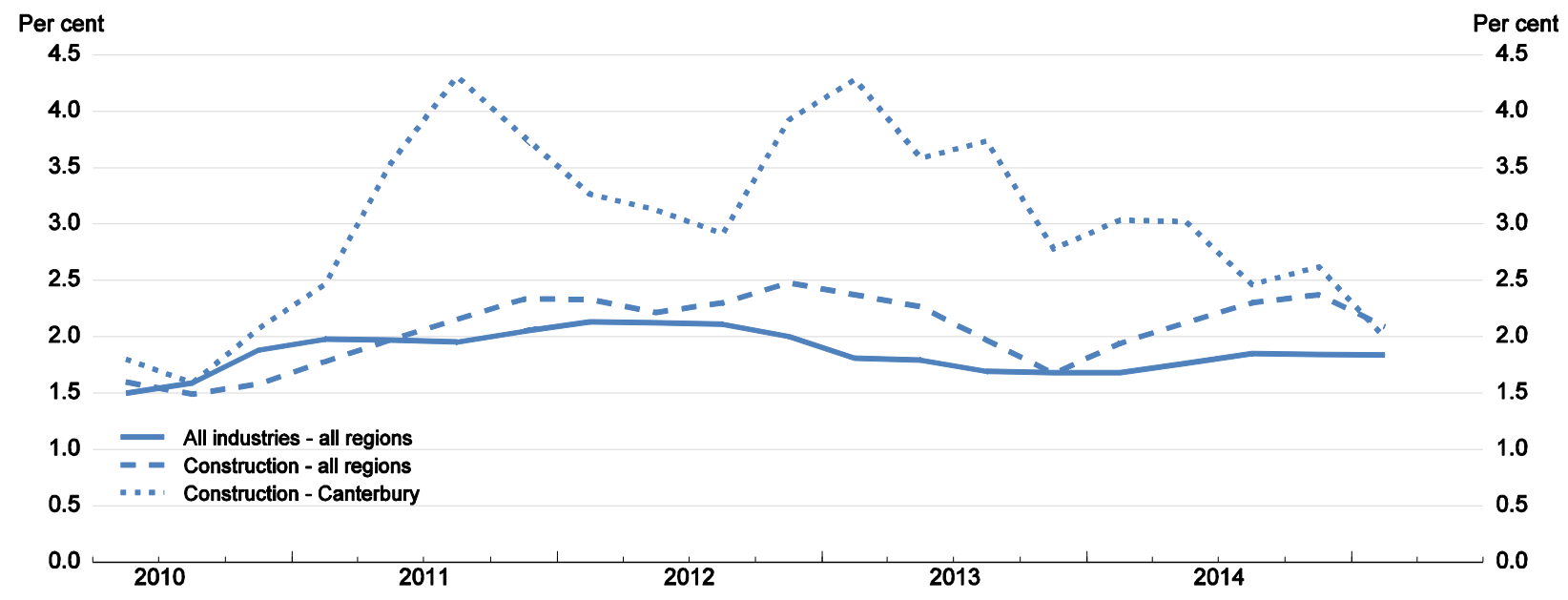

1. All salary and wage rates.

Source: Statistics New Zealand.

\section{Skills shortages and the role of education and training}

Data on skills premiums suggest skills shortages are limited in aggregate, but that higher returns to health, engineering, ICT and management degrees may suggest some shortages in these fields. Returns to tertiary education (both university Type A and college Type B) relative to secondary school in New Zealand are comparatively low (OECD, 2014a), and tertiary wage premiums have moderated slightly in the latest data (for 2012) compared with those for 2000. While these low returns and their moderation since 2000 may reflect the country's low productivity, with wage rates reflecting the marginal product in a 
competitive market (OECD, 2013), measurement issues are also important. Tertiary returns are evaluated relative to secondary returns and the latter may be boosted by a large stock of tertiary vocational education and training (VET) non-completers in New Zealand. In addition, a large share of tertiary-educated immigrant inflows may at least initially experience lower earnings than their native-born counterparts, lowering tertiary returns directly. Although these factors may account for roughly half of the gap in tertiary returns relativeto the OECD average, after their removal New Zealand's private returns to tertiary education remain relatively low (Zuccollo et al., 2013). It is also important to note that these data are only collected for one's highest degree; therefore, they do not account for the potential contribution of previous degrees to tertiary returns.

Earnings premiums vary considerably by field of study. The highest bachelor-degree premiums are in health, engineering, information technology and management (Figure 5). New Zealand tends to graduate a low share of engineering students compared to other countries (OECD, 2014a). In response to these potential engineering skills shortages, the government has expanded engineering positions in universities and reduced applicable tuition fees. Wage premiums are also associated with ICT, but it is unclear from the labour data whether skills shortages have become more prevalent, as the frequency of reports of hard-to-fill vacancies in these disciplines has tended to decline since 2008. However, reports of shortages (e.g. New Zealand Productivity Commission, 2014a) may reflect experience and industry relevance. There may also be a need for higher-level skills, with entry into advanced research programmes lower than in best performing countries, particularly when excluding international students (OECD, 2014a). In the services sector, more effective use of ICT could improve labour productivity. Firms that produce or use ICT intensively tend to have higher productivity than others, and the uptake of ICT may be limited by these skills shortages or a lack of managers with ICT know-how (New Zealand Productivity Commission, 2014a). The government has responded by announcing in its 2014 Budget plans to establish ICT graduate schools in Auckland, Christchurch and Wellington, close to high-technology companies, to enhance university-industry linkages and internship opportunities. This may better prepare ICT graduates for employment and ensure that these degree programmes remain relevant to the marketplace.

\section{Figure 5. Earnings premium five years after study}

Percentage gap over median earnings for level 1-3 certificate

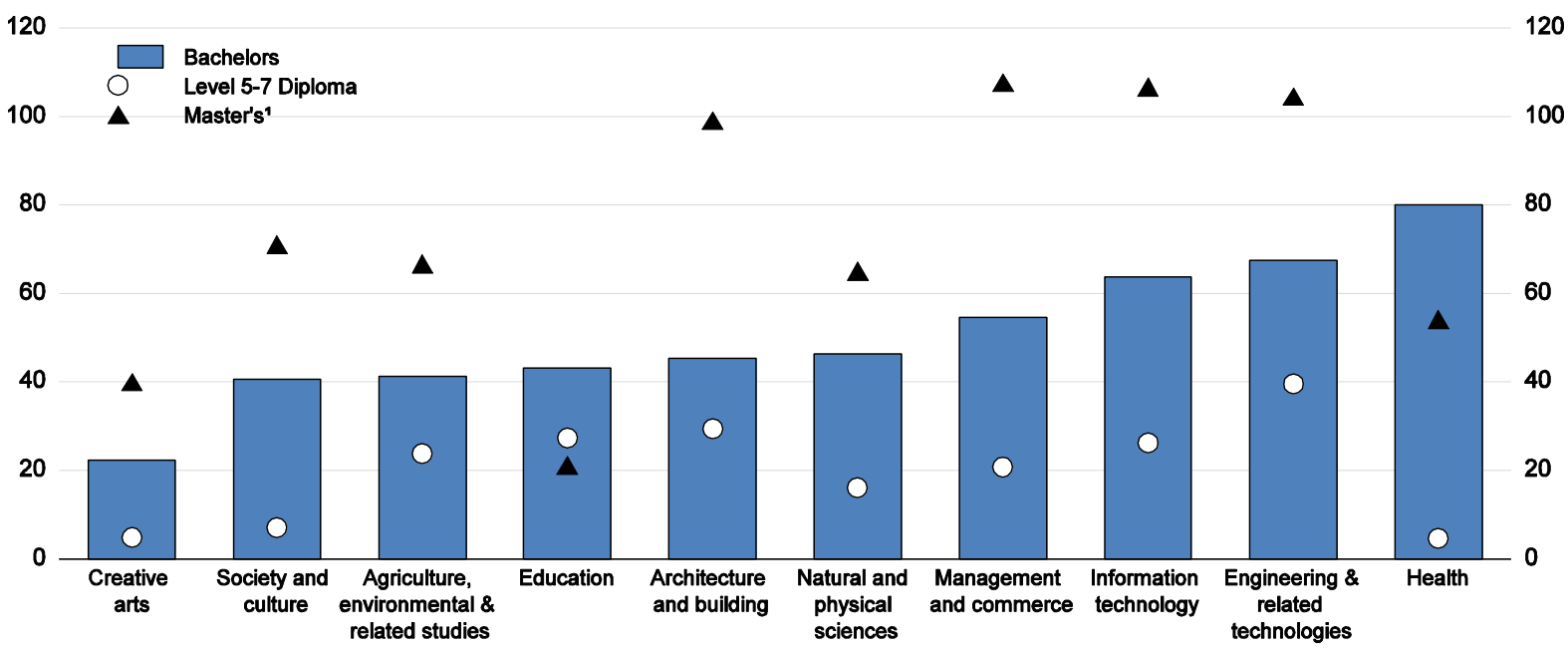

1. The lower earnings premium for Master's graduates in education than Bachelor's graduates results from a move towards parttime employment amongst the Master's graduates in the study.

Source: Mahoney et al. (2013), Moving on Up - What Young People Earn After their Tertiary Education; OECD calculations. 
Shortages of qualified managers have been most evident in large firms, and these may be constraining business scale in New Zealand (Figure 6). This could be costly, as large NZ firms are more likely to export, face greater competition, adopt new technology, innovate and have better outcomes in terms of sales growth, productivity and profitability (Statistics New Zealand, 2015). In addition, a lack of managerial resources was the most frequently cited factor hampering business innovation, which may have constrained productivity growth more generally. These results also appear to hold true on a cross-country basis: firms with greater assessed managerial quality also tend to have higher productivity, profitability and growth rates and are less likely to exit due to bankruptcy (Bloom et al., 2012).

\section{Figure 6. Firm size and recruitment difficulties}

Percentage of firms surveyed reporting moderate or severe difficulties, last financial year at August $2014^{1}$

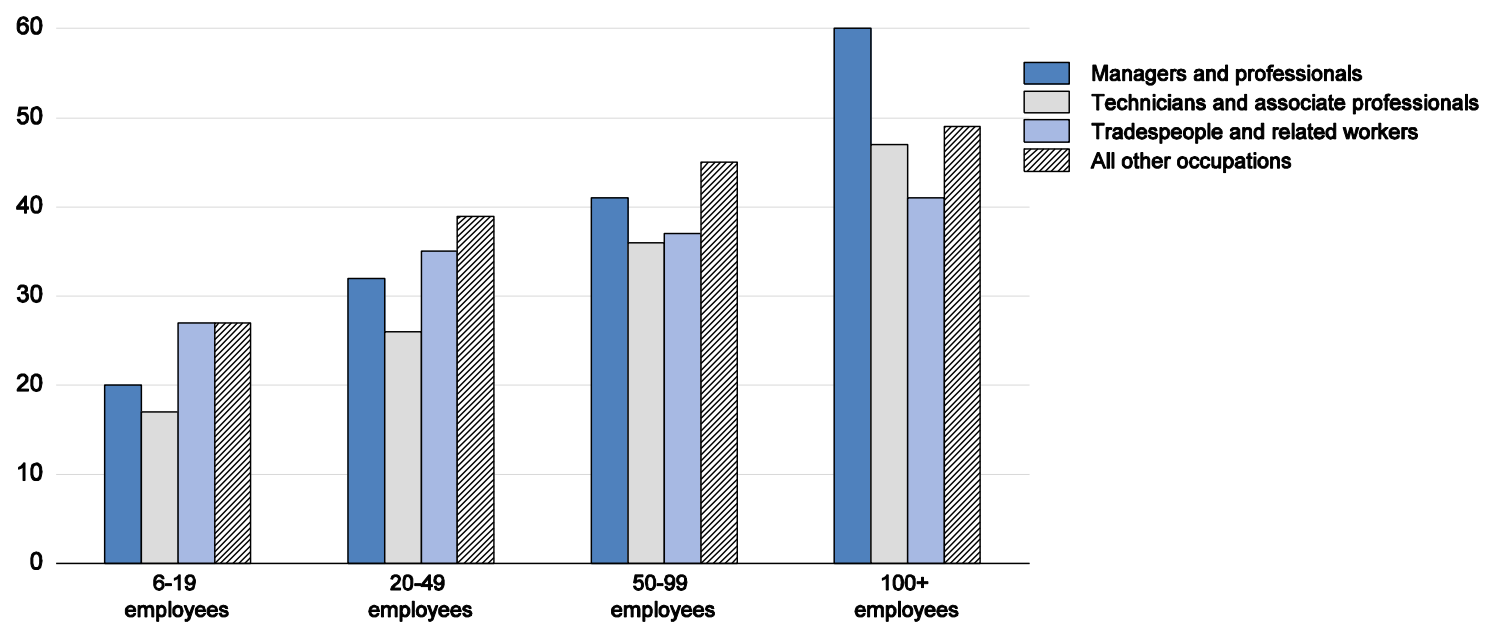

1. Last financial year refers to the last financial year for which businesses had results available in August. Financial years for businesses finish on 31 March in New Zealand.

Source: Statistics New Zealand, Business Operations Survey: 2014.

New Zealand's policy environment is generally conducive to competition and managerial quality, with comparatively low product market regulations and employment protection legislation (Figure 7). In such an environment, surviving firms should be better managed and more productive. Graduates of business and administration are also numerous as a share of the population relative to other countries (OECD, 2013); however, better equipping a broader range of graduates of other disciplines with management or soft skills may be required. In addition, implementing policies that could foster greater competition in the domestic market could also be positive for growth. For instance, foreign multinationals appear to have better management practices than NZ firms, which is also true of other host countries (Bloom et al., 2012). Such firms appear able to call upon better management practices in different situations; enabling further foreign direct investment (FDI) may therefore lead to spill-overs in terms of management expertise. Improving the FDI screening regime, by reducing complexity and restricting the scope of investments considered sensitive, could potentially aid in increasing competition and business scale, thereby encouraging higher productivity growth. 
Figure 7. Regulations affecting the business climate, 2013

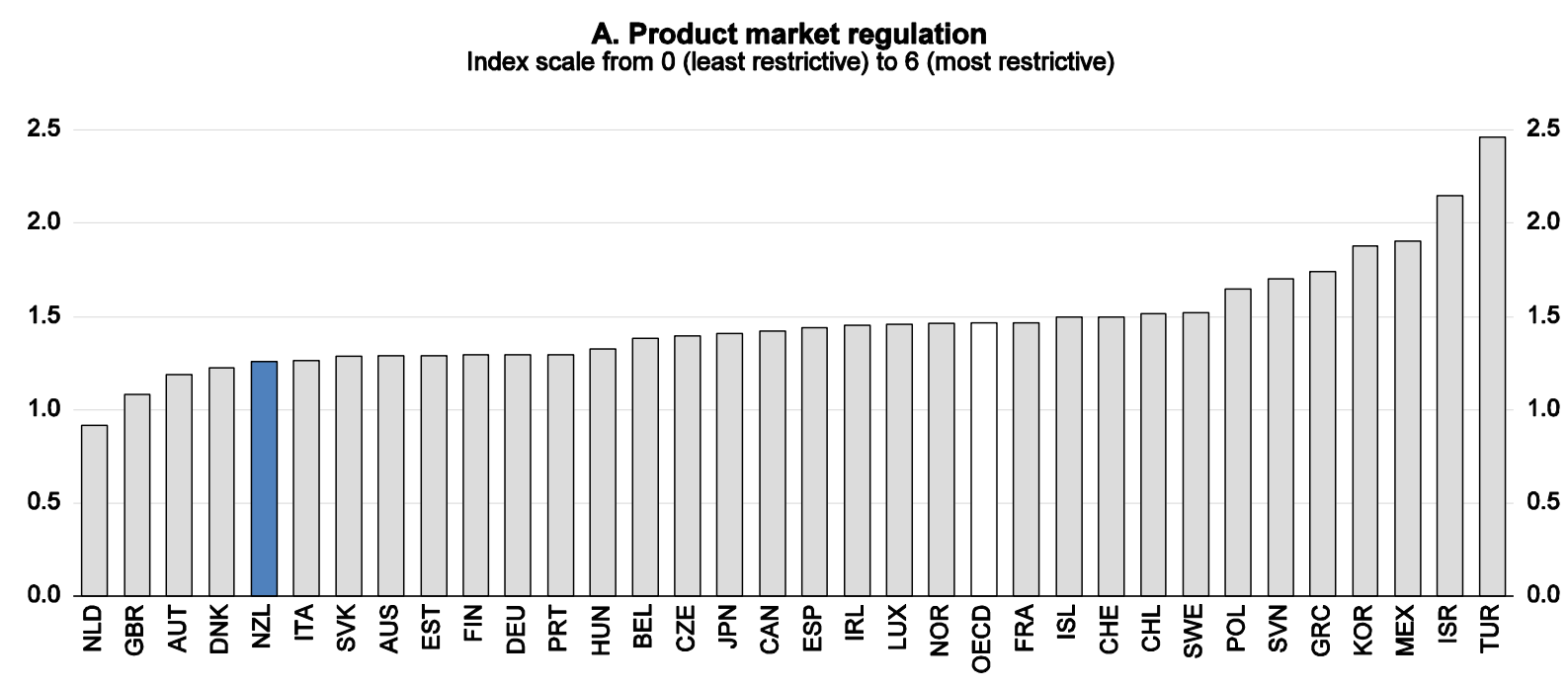

\section{B. Employment protection legislation' Index scale from 0 (least restrictive) to 6 (most restrictive)}

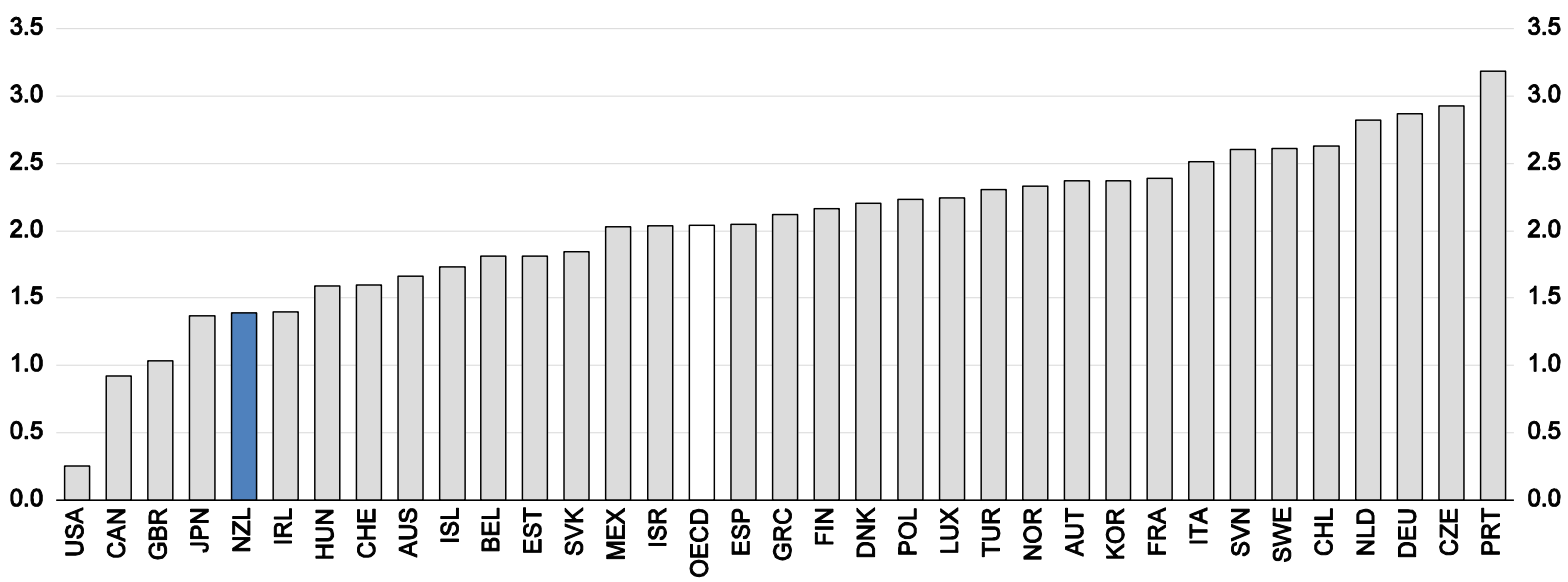

1. Protection of regular workers against individual and collective dismissals.

Source: OECD, Product Market Regulation and Employment Protection Legislation databases.

Concerned that low returns to tertiary education may reflect students' poor degree choices, the government has increased the amount of information that students have when making career choices, including the Occupational Outlook, which provides information on career paths, employment prospects and educational requirements to prospective students. The Vocational Pathways programme has also been implemented to provide clearer information about employment prospects and more diverse ways of obtaining foundational skills to move into employment. In addition, the government has published data on graduate outcomes across fields and levels of study; however, centralising such information to make it more readily available to students could help. Regional initiatives, such as the Work Force Skills Roadmap for the Auckland Construction Sector, provide information to VET providers regarding medium-term construction skills needs. Skills for Canterbury focuses on skills gaps for the rebuild. Continuing to develop these linkages will probably aid in addressing skills needs. 


\section{Migration and targeted initiatives have reduced skills shortages, particularly in Canterbury}

Migration plays a key role in labour market adjustments. Both permanent, work-related immigration and temporary migration are high compared with other OECD countries (Figure 8). While permanent immigration reflects more than just work-related movements, a large share of these migrants originally entered on a temporary basis (OECD, 2014d). In addition, the free movement of labour between Australia and New Zealand has buffered the gap between labour supply and demand. While there tends to be a net outflow of New Zealanders, including skilled workers, because of longstanding income differentials, this brain drain tends to be offset by skilled immigration from other sources. Migration also feeds into New Zealand's international development agenda. Short-term workers from the Pacific are admitted through the Regional Seasonal Employer programme to fill seasonal labour shortages in the horticulture and viticulture industries. While in New Zealand these temporary migrants can receive broader skills training through targeted programmes such as Vakameasina (OECD, 2015b).

Figure 8. Overall migration

\section{A. Permanent immigration}

Per cent of total population, 2012

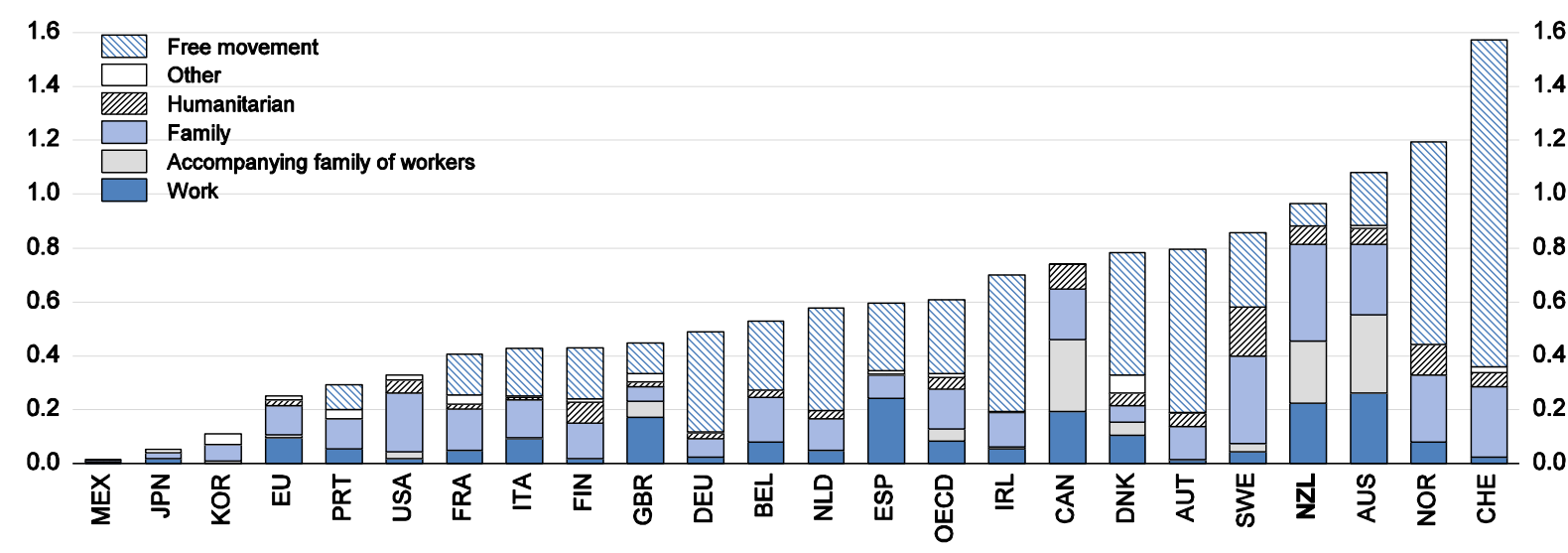
B. Temporary labour migration
Per cent of the labour force

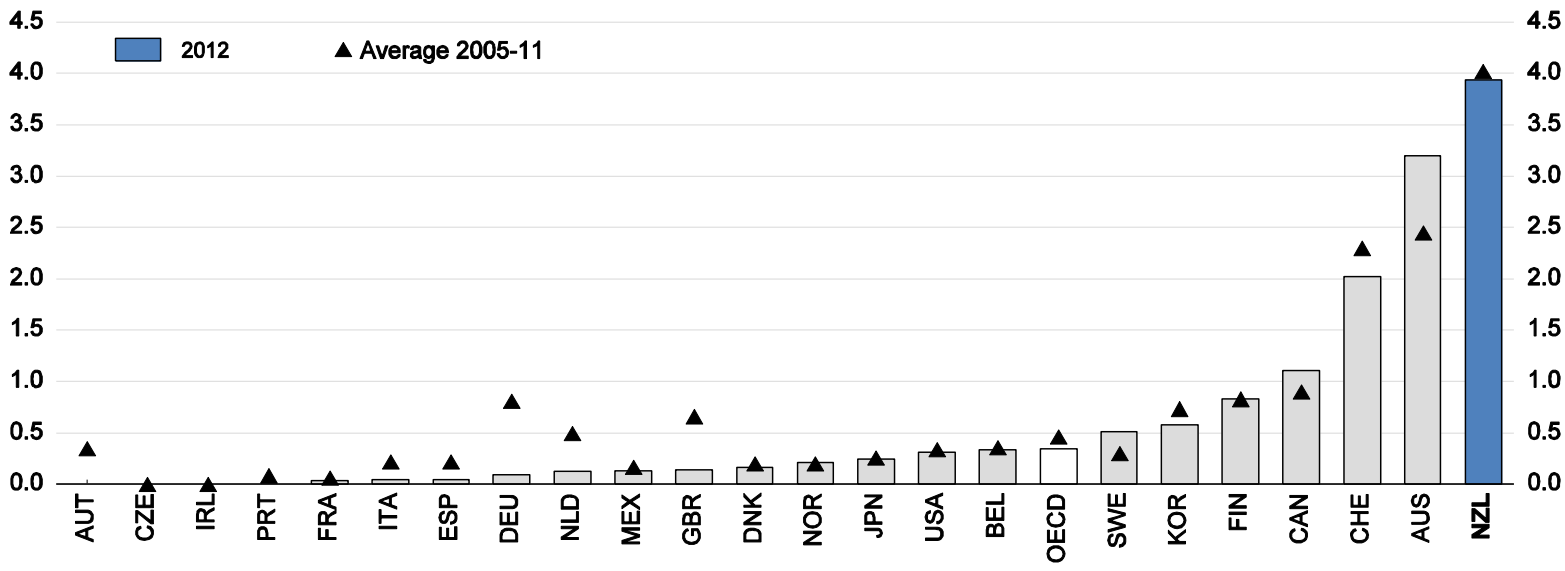

Source: OECD (2014), International Migration Outlook and International Migration database. 
A key element of population growth in this cycle has been the strong rise in net permanent and long-term (PLT) migration (Figure 9), and its recent strength has probably helped to limit labour shortages and reduce overall wage pressures. This partly reflects an increase in arrivals with work visas, suggesting that more migrants may participate in the labour market in this cycle, thereby adding to the economy's productive capacity. Moreover, fewer departures of NZ citizens and a modest increase in return migration have also contributed to domestic labour supply, reflecting improved job prospects at home and weaker employment growth in Australia. In the medium term, greater arrivals of non-citizens and fewer net departures of NZ citizens, both of whom tend to have higher education levels than non-migrating New Zealanders, will probably bring longer-run benefits by complementing local labour skills (Docquier et al., 2014). Higher shares of migrants also tend to be of working age and therefore are more likely to participate in the labour market than the resident population. Furthermore, immigration can lead to a larger economy, resulting in scale and agglomeration effects and increased international connectedness, though the size of these effects in New Zealand is much debated (Fry, 2014). However, high levels of net immigration add to demand for housing and infrastructure, where strains are already apparent in Auckland, the main destination for new arrivals.

Since the 2003 reforms, New Zealand's immigration system has placed a heavy weight on skills, employment and work experience, probably contributing to the very good record of integrating immigrants into labour markets and society. There is evidence of lower returns on skills paid to immigrants upon arrival compared with their NZ counterparts, but these gaps become insignificant after 10 years (Maré and Stillman, 2009). These wage differentials may indicate lower human capital, potentially related to soft skills, local labour market knowledge, language abilities or imperfect transferability of skills. To further improve labour market integration it may be beneficial to increase the weight given to English-language proficiency in the immigration process or to provide further support and monitoring of language training completions (OECD, 2014d). Recent changes in student visas, which now provide work rights, will probably aid in building soft skills, thereby boosting human capital, potentially further improving students' eventual labour market outcomes. Increased monitoring of skills shortage categories, which may require a more frequent updating and refinement of categories, could better ensure the attraction of the right number of people with appropriate skills.

In addition, New Zealand's demand-driven model could potentially benefit from more regular updating of the immigration targets, as in Australia and Canada, and from wider tolerance ranges for the three-year immigration targets or a higher cap to allow more flexibility based on evolving economic conditions. The current system may limit needed immigration during sustained expansions and may induce cyclical constraints on admittance. Under buoyant labour market conditions it may be more difficult to immigrate than under less favourable conditions when pass marks for permanent migration could potentially be adjusted downward to meet targets (OECD, 2014d). However, improving the responsiveness of housing supply would be necessary before materially raising migration targets.

While most migrants settle in the Auckland region, rising numbers have gone to Canterbury since 2011 to fill skilled labour vacancies for the rebuild. This is shown by a rapid expansion in Essential Skills visas over this period, both for construction-related and other jobs. In addition, the net migration of NZ construction workers to Greater Christchurch, which had been negative over 2011-12, has turned neutral or slightly positive recently (MBIE, 2014a), suggesting that formerly expatriate New Zealanders and more NZ citizens who would have typically emigrated to other countries may also be working on the rebuild. Given its pressing and time-limited character, immigration is the best way to meet these labour shortages. 
Figure 9. Permanent and long-term migration

March data

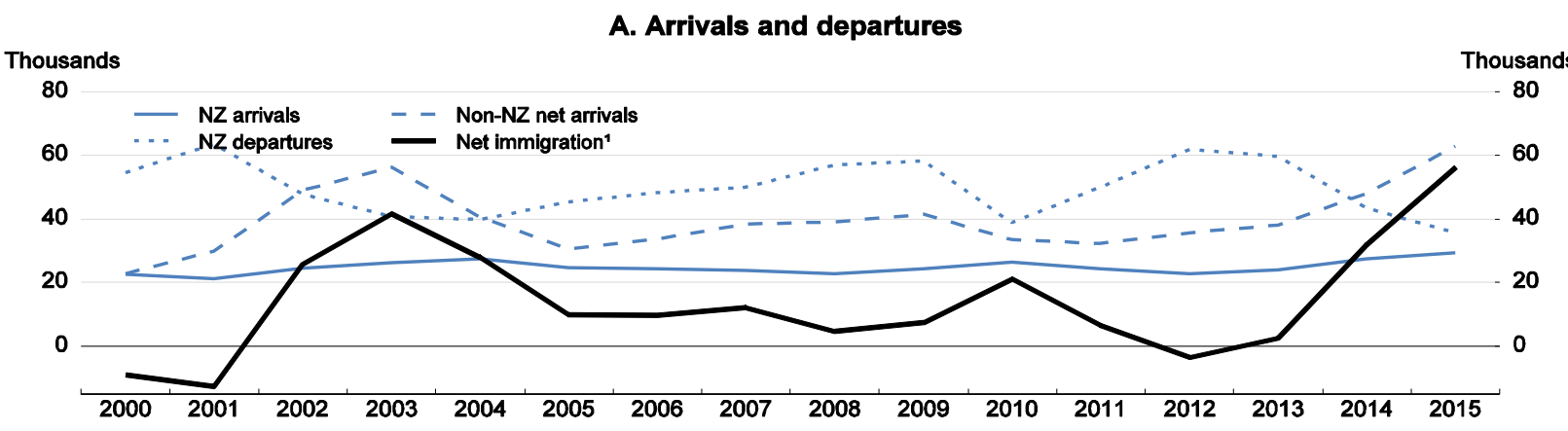

B. Arrivals by visa status ${ }^{2}$

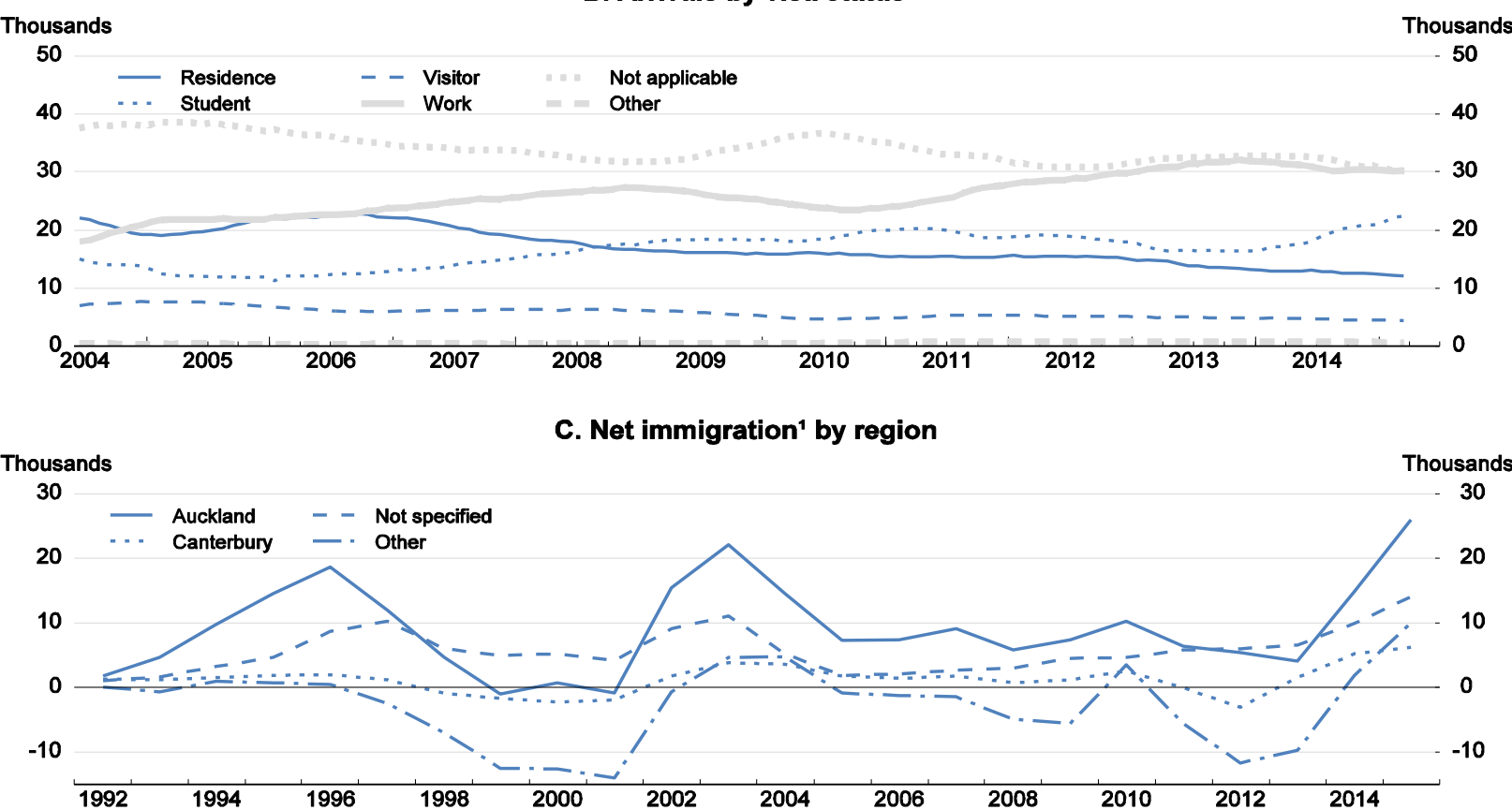

D. Net emigration ${ }^{3}$ to Australia and employment growth

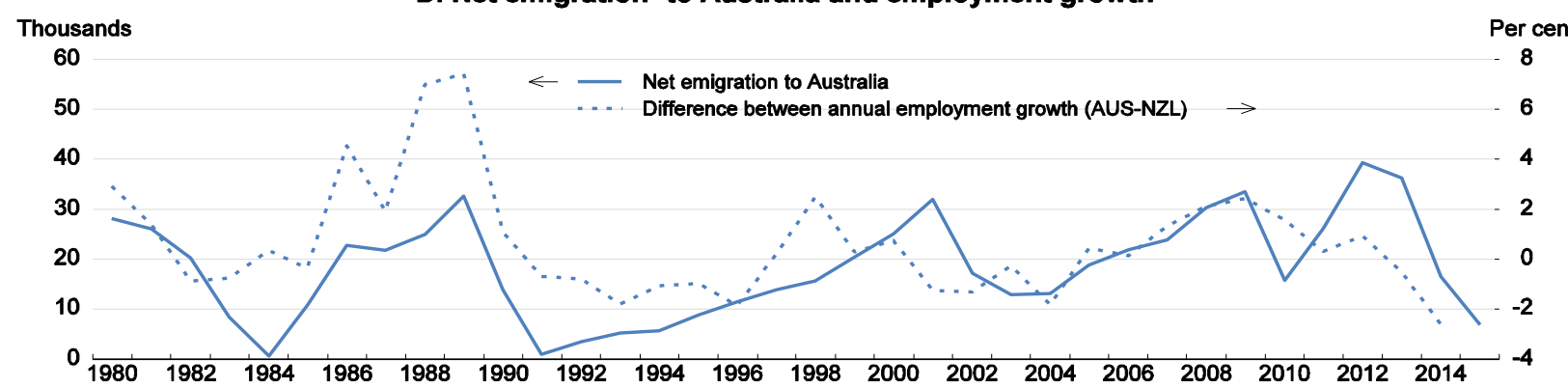

1. Arrivals of overseas migrants in New Zealand for a period of 12 months or more as well as of NZ residents returning after an absence of 12 months or more, minus the departures of NZ residents for 12 months or mor and of overseas visitors after a stay of 12 months or more.

2. Twelve-month moving average annualised.

3. NZ citizens returning from Australia after a stay of 12 months or more minus NZ citizens departing for Australia for 12 months or more.

Source: Statistics New Zealand, International Travel and Migration database. 
To facilitate the reallocation of labour to Canterbury for the rebuild, the government started several initiatives in order to improve labour market matching and to speed up the immigration process. This includes the Canterbury Skill Shortage List (CSSL), which is a temporary occupational shortage list for medium- to high-skilled jobs and is similar to the Immediate Skill Shortage List (ISSL) at the national level, although it undergoes more frequent updating. It applies to occupations where it is deemed that there are insufficient numbers of New Zealanders or training completions to fill skills demand. Jobs on the CSSL do not require a labour market check before employers can recruit migrants and obtain for them an Essential Skills visa. The majority of the jobs awarded through CSSL are in construction, engineering and trades (OECD, 2014d).

A second initiative has been the Canterbury Skills and Employment Hub ('Hub'), which is focused on speeding up the labour market matching for semi-skilled and unskilled occupations, which typically fall outside of CSSL, but higher skilled occupations can still be listed. The Hub first matches NZ jobseekers (including beneficiaries) with employers seeking vacancies, before a migrant can be hired. If no suitable New Zealander or permanent resident is identified, the Hub then provides a letter in support of an Essential Skills visa application, which enables the application to be fast tracked. Other initiatives for the rebuild have included providing relocation assistance (NZD 3000 ) for the unemployed to relocate to Canterbury for full-time positions (up to a maximum of 1000 applicants) and extending the right to work for English-language students in Canterbury since 2012; however, part-time work rights are now a feature of student work visas more broadly. The maximum duration of Essential Skills visas for lower-skilled occupations will be raised from one to three years for applicants between July 2015 and December 2016, for work in Canterbury. In addition, from 1 July 2015 onward, holders of these visas working in Canterbury will be able to change employers without having to apply for a Variation of Conditions on their visas, provided they remain in the same occupation. These changes should help to reduce labour market frictions and provide immigrants with greater job security and protection against potential exploitation.

The determination of shortage lists for both CSSL and ISSL is fairly labour intensive, reflecting poor information on jobseekers and vacancies, and the procedure for obtaining essential skills visas may be overly complex (OECD, 2014d). In the case of ISSL, which is applied nationwide, the shortage list is updated at an annual frequency and as a result may not respond as quickly to evolving labour shortages as CSSL. This may impede matching at a national level if the labour market tightens more broadly in the cycle, constraining overall output and productivity. Extending the lessons of the Hub to the national level could improve labour market matching, easing constraints as labour markets tighten. Recent official assessments suggest that the Hub has had favourable outcomes, and the government is considering trials in other regions.

\section{Housing supply and population growth}

Strong net inward migration has bolstered the economy's productive capacity but has also added to regional housing pressures. House price increases have been considerable over the past few years, and, relative to long-run averages, prices are high compared to income and rents by OECD standards (Figure 10). The largest increases have been in Auckland, where prices are high relative to median incomes (Demographia, 2015) by international comparison. Here, housing affordability is poor by historical standards, despite relatively low interest rates (Massey University, 2015). 
Figure 10. House prices
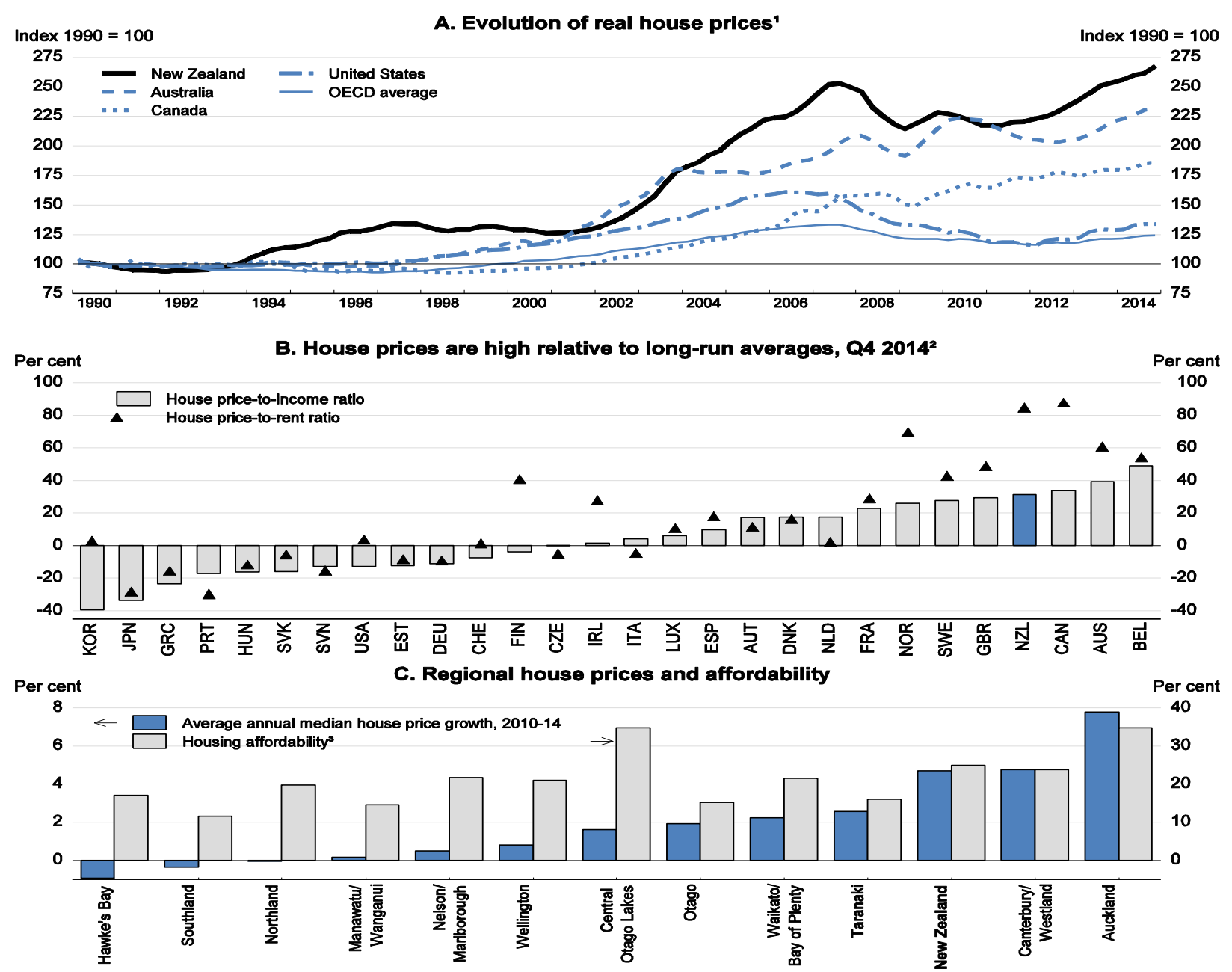

D. Medlan house price relatlve to medlan household Income, Q3 2014

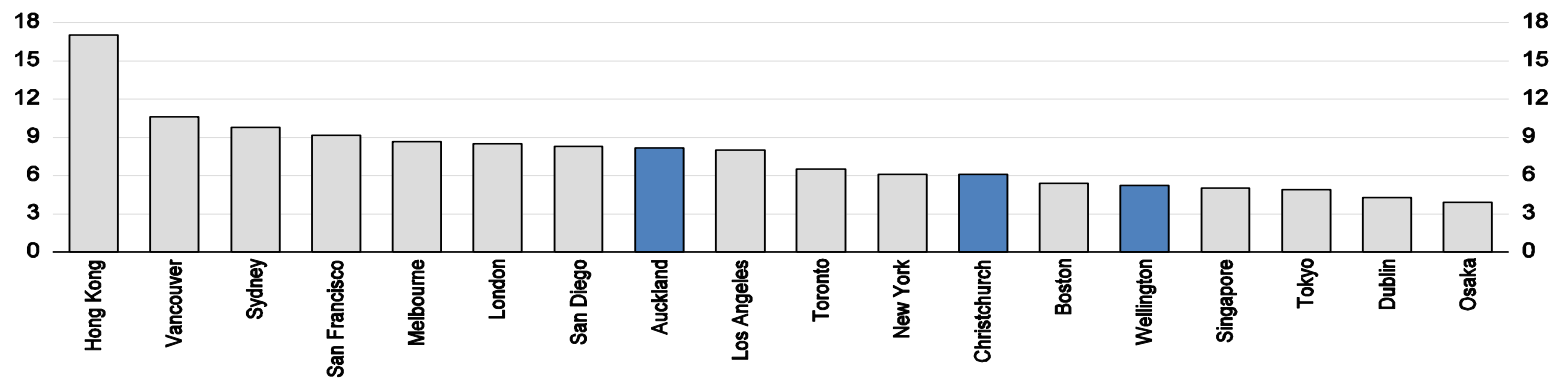

1. Nominal house prices deflated by the private consumption deflator.

2. Deviation of the ratio nominal house prices/nominal disposable income per capita (or/rent prices) over the long-term average. Q4 2014 or latest available quarter.

3. The affordability index defined by the Massey University Real Estate Analysis Unit takes the ratio of the weighted mortgage interest rate as a percentage of median selling price to the average wage. The lower the index, the more affordable the housing.

Source: OECD, Housing Prices database; Real Estate Institute of New Zealand; and Massey University Real Estate Analysis Unit, Home Affordability Report, various quarterly reports, www.masseynews.massey.ac.nz; Demographia (2015), 11th Annual Demographia International Housing Affordability Survey: 2015. 
As highlighted in the 2011 Survey (OECD, 2011; Cheung, 2011), the Auckland house price boom reflects, at least in part, constrained housing supply, which has failed to keep pace with demand. A large share of the population growth and immigration has been centred here (Figure 11, Panel A), resulting in significant increases in house prices. Empirical evidence has shown that New Zealand tends to experience stronger long-run population growth effects on house prices than other OECD countries (Caldera and Johansson, 2013), which might reflect constrained supply. In particular, the responsiveness of supply to rising house prices is around average for OECD countries but roughly half that of the best performing countries. This is problematic, as New Zealand's population growth has been faster than average and somewhat more variable (Figure 11, Panel B).

\section{Figure 11. Population growth}

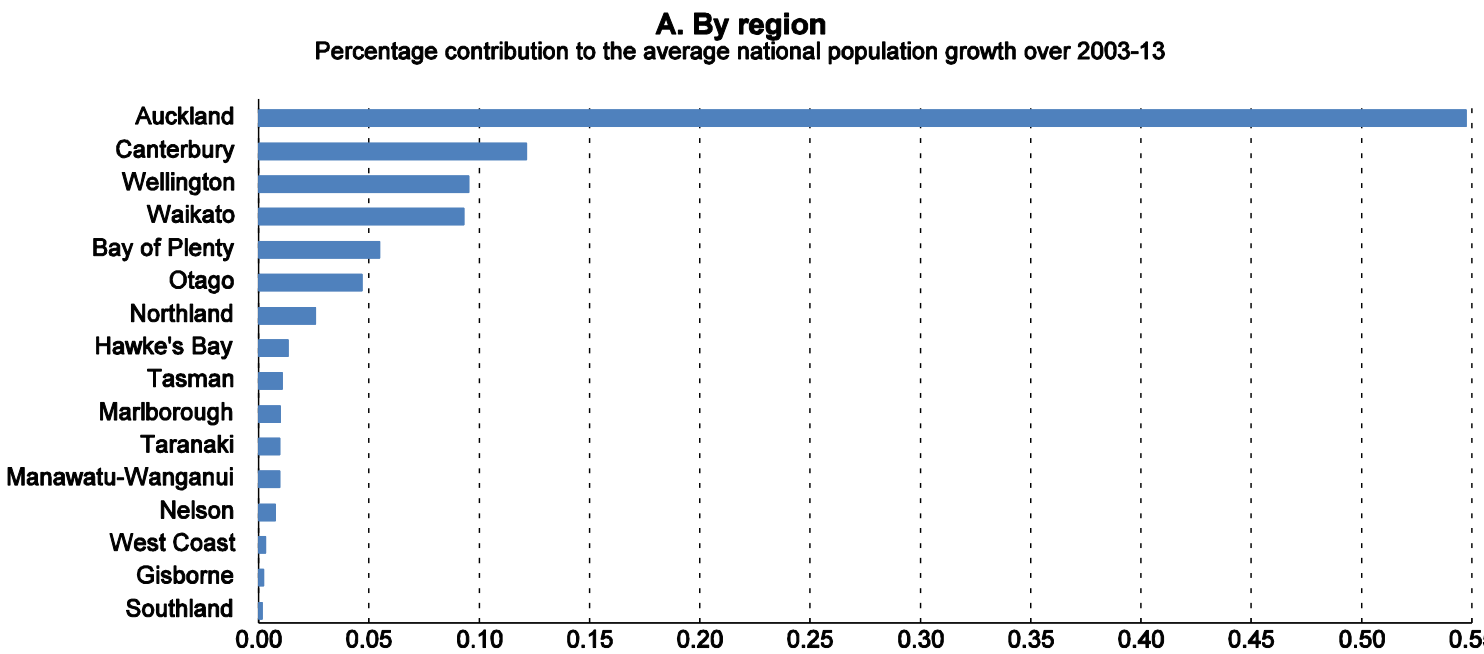

B. Cross-country comparison
Average 2003-13, ${ }^{1}$ per cent

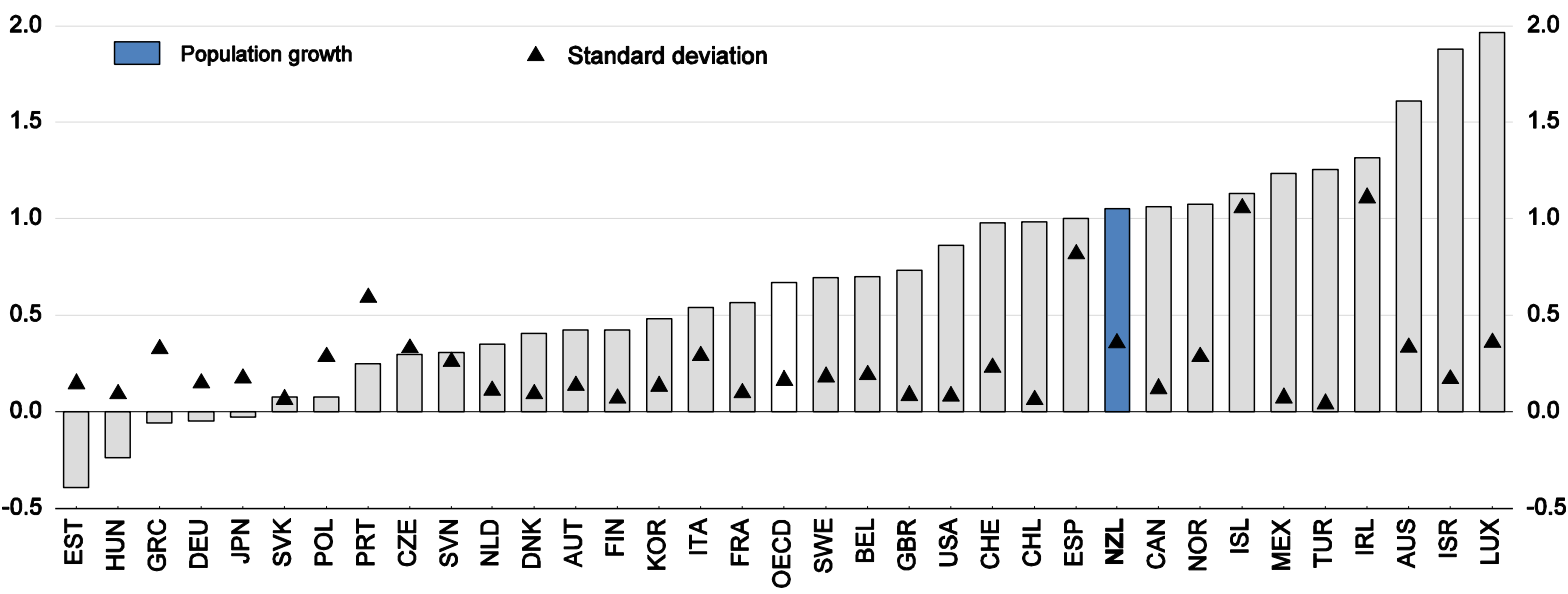

1. Or last 10 years available.

Source: Statistics New Zealand, Estimated Resident Population for Regional Council Areas, at 30 June, Table DPE051AA; OECD, Population Statistics database.

The recent strength in population growth has been driven by robust net PLT migration, while the natural increase has been the lowest since 2005 (MBIE, 2014b). House price pressures from heavy net PLT migration may be more subdued than in past migration cycles, as a large share of net migration has resulted 
from fewer NZ citizens leaving the country and more returning. According to McDonald (2013), lower net departures of NZ citizens have roughly half the impact on house prices as an equivalent increase in net arrivals of non-citizens. Despite this, constrained supply may lower Auckland's ability to attain agglomeration economies, through restraining labour mobility and reducing incentives for firms to locate there. In addition, rising house prices could act to dampen growth during the cycle by reducing competitiveness. In particular, rising house prices could increase the wage rates that employers need to offer to attract or retain labour, increasing costs for businesses that have limited ability to substitute cheaper capital. In the absence of an increase in productivity, unit labour costs would deteriorate and could reduce Auckland's competitiveness. Such a scenario seems to have occurred in France, for example, a few years ago (Egert and Kierzenkowski, 2010).

\section{Supply responsiveness should continue to be targeted for improvement}

The price responsiveness of housing supply in New Zealand may be lower than in best performing countries due to the time it takes to deliver building sites and complete dwellings. The responsiveness of supply depends not only on geography and urban characteristics, but also on land use regulations and planning restrictions. These regulations may have been increasingly binding in Auckland where the soon to be expanded Metropolitan Urban Limits (MUL) have been a constraint on supply. This has been reflected in land prices in and near Auckland, which have grown faster than in other regions and account for roughly $60 \%$ of the price of a home, relative to $48 \%$ elsewhere (New Zealand Productivity Commission, 2014b) and may have contributed to increasing further the already high number of people per dwelling relative to other regions (Figure 12).

Figure 12. Population-to-dwelling ratio

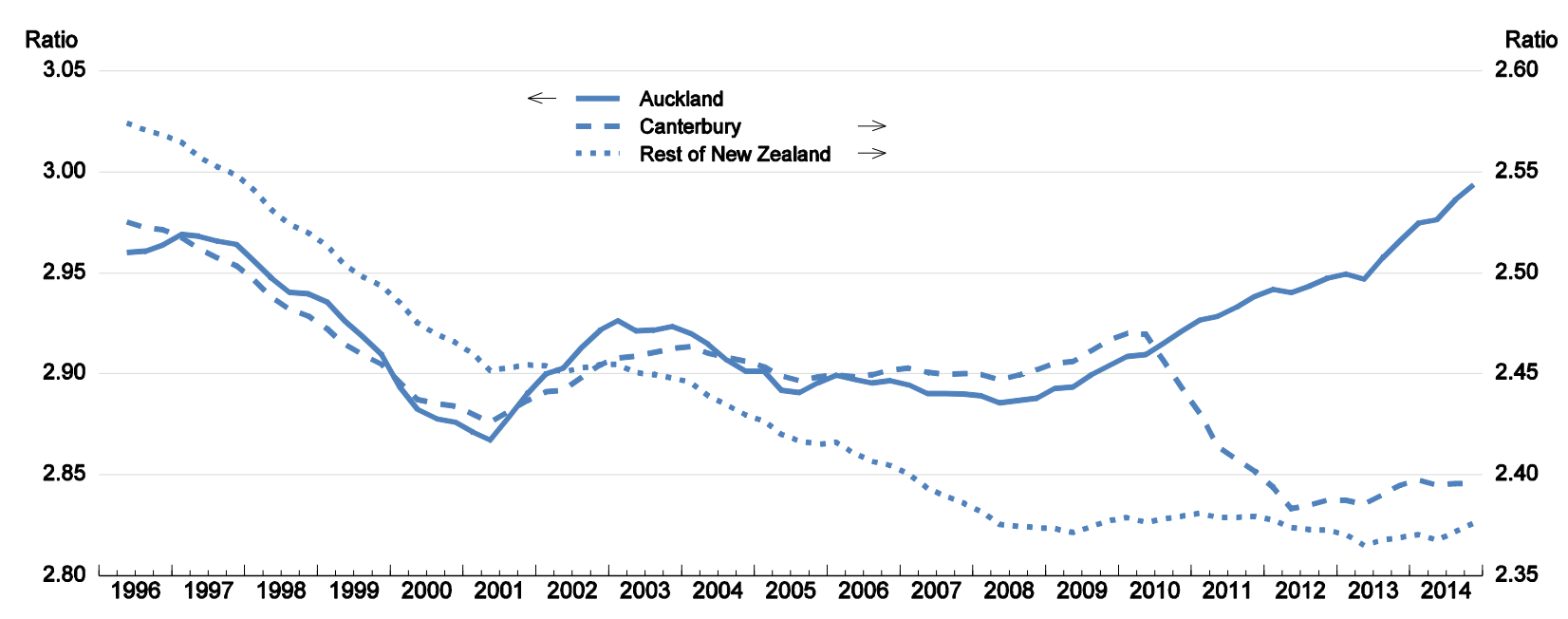

Source: Reserve Bank of New Zealand, Financial Stability Report, May 2015.

Furthermore, land values just inside the MUL have been between 8 and 13 times those outside (Grimes and Liang, 2007). In supply-constrained markets, a large share of the adjustment to increased demand occurs in the price dimension rather than in increased supply (Glaeser et al., 2008; Gyourko and Molloy, 2014). This is consistent with results for New Zealand, with local authorities with low supply elasticities tending to have high price responses to demand shocks, probably due to regulatory constraints (Grimes and Aitkens, 2010). According to a Demographia (2015) survey on housing affordability, which considers house prices in major metropolitan areas in several advanced economies, all cities with housing markets considered severely unaffordable had some form of restrictive land use policies in place. 
NZ land-use planning takes place at the local council level, and, as highlighted by the New Zealand Productivity Commission (2012), planners have had to deal with a wider range of issues through time, from land use planning initially to a broadening mandate that incorporates infrastructure provision, environmental sustainability and economic resilience. Therefore, there may be a need to better equip local councils to deal with more complex land-use planning. Regulations, including the Resource Management Act (RMA), are highly devolved, so more central guidance would be beneficial to ensure consistency with environmental goals, and to reduce the scope for vested interests to limit competition or thwart rezoning and development that would be in the wider public interest. Further guidance could also limit unnecessary duplication of efforts at local levels and business uncertainty related to varying application of regulations across regions. Furthermore, extensive rights of appeal inherent in the RMA increase development uncertainties.

While regulations are essential to ensure that externalities, such as those impacting the environment, are properly taken into account in economic decisions, designing and implementing them in a way that is most friendly to competition and entry is crucial to minimise their economic burden, which, in general, is relatively high in New Zealand (Figure 13). This does not appear to be related to their perceived stringency but reflects relatively high administrative burdens associated with permitting and licensing (Koźluk, 2014). While this would likely apply to a broad range of economic activity, the building industry has probably borne a large share of the costs, with the majority of permits processed through the RMA being for land use changes (New Zealand Productivity Commission, 2014b). For residential construction current regulations, including land-use and planning rules, may have added between NZD 32500 and 60000 per dwelling in subdivisions and between NZD 65000 and 110000 per apartment, increased construction times and reduced the likelihood of development, particularly of affordable housing (Grimes and Mitchell, 2015).

\section{Figure 13. Burdens on the economy due to environmental policies and policy stringency}

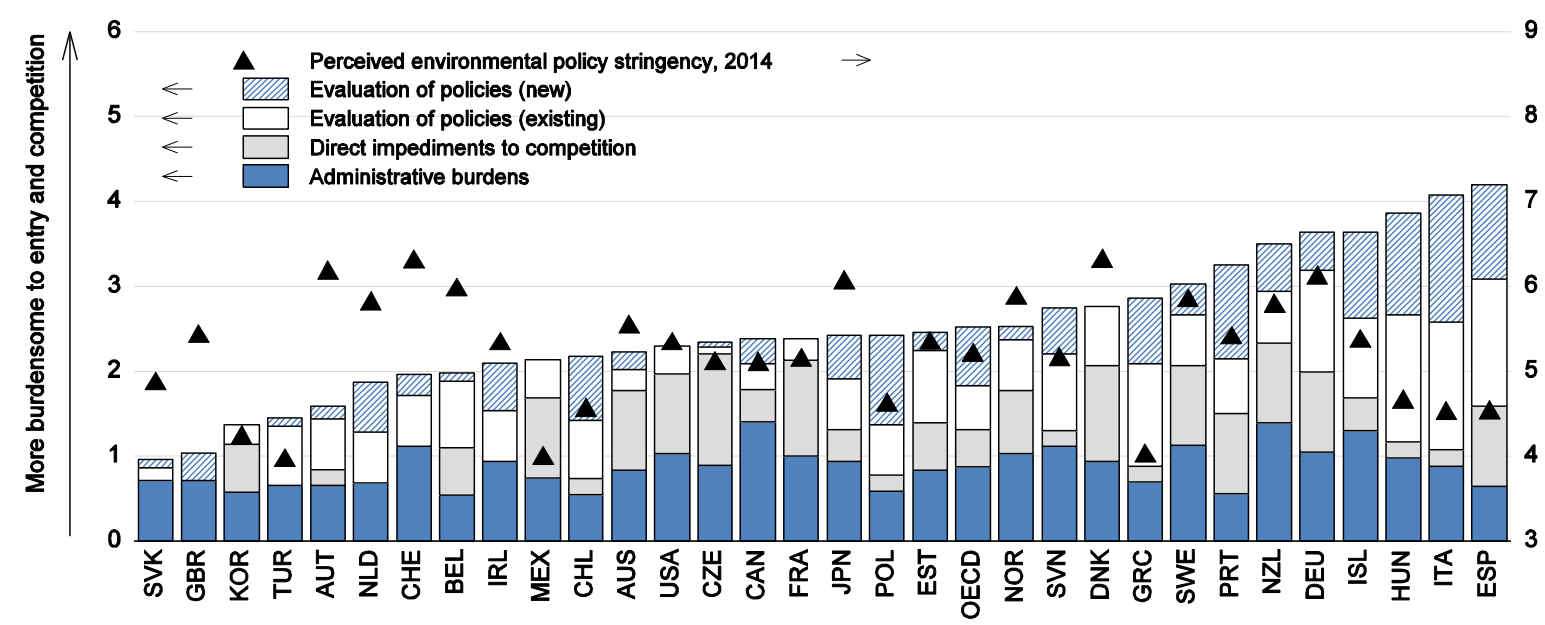

Source: T. Kozluk (2014), "The Indicators of the Economic Burdens of Environmental Policy Design - Results from the OECD Questionnaire”, OECD Economics Department Working Papers, No. 1178, ECO/WKP(2014)74; World Economic Forum (2014), Executive Opinion Survey; and OECD calculations.

In the Housing Action Plan, the Auckland Council identified a shortfall of 20000 - 30000 dwellings and a need for 13000 dwellings to be built each year for the next 30 years (Auckland Council, 2012). Although there is uncertainty around these estimates, with new census figures potentially supporting a slightly lower shortage (Auckland Council, 2013), much larger shortfalls could be estimated if the average number of people per household in Auckland were closer to the lower country-wide average (BNZ, 2015). 
Overall, most shortage estimates are within or close to the lower end of the range provided in the Housing Action Plan (BNZ, 2015). While building permits have risen, they are still running below projected demographic requirements. This said, some progress is being made to release land for development and speed up the consenting process, which should improve the supply of land in the medium to long term. In particular, the Auckland Housing Accord (approved in September 2013) between the national housing minister and the mayor focuses on accelerating housing supply, until the Auckland Unitary Plan becomes operational in 2016. Through the Accord, Special Housing Areas (SHAs) have been created, which offer a fast-track consenting process, rather than having to comply with the timelines set out in the RMA, with limited appeals, and this should speed development.

The creation of the Auckland Council's Housing Project Office to implement the Housing Accord has been instrumental in pulling together skilled planners, infrastructure and environmental specialists to quicken housing supply and has permitted more integrated planning, a recommendation from the 2011 Survey. However, skills shortages probably limit the scope to scale up this model further in Auckland and more broadly. Therefore, there is a need to better equip local councils through improved training and increased resources to undertake the planning process and provide more opportunities for integrated planning.

While the Metropolitan Urban Limits will be expanded through the Proposed Auckland Unitary Plan, a large share of the development envisioned over the next 30 years is to occur within previous city limits, which contains some greenfield land, but a significant portion is to take place through infilling, rezoning and building high-rise structures. However, countering community resistance may prove difficult. Densification objectives in the Auckland Unitary Plan were significantly scaled back during the consultation phase, largely reflecting resident opposition to rezoning. Several commentators have pointed out that NIMBYism ("not in my backyard") has played an important role in slowing the pace of housing supply and in reducing densification and has resulted in the proposed Plan having stricter zoning in some areas than was previously the case (e.g. NZIER, 2014; Auckland Council, 2014).

To raise supply and encourage densification it will be important to find ways to increase community support for densification. A greater central role in dealing with local objections might take some pressure off municipal governments. There may also be a need to extend beyond the SHAs the limitation of appeals to those directly affected to augment the housing supply response. Overall, industry analysis supports the view that unless significant rezoning takes place, and is accepted by residents, goals of developing within established urban areas to meet annual targets for new dwelling construction will not be met (MBIE, 2013). In addition, freeing up crown and council land could also make way for further development, particularly of affordable dwellings.

\section{Increasing resources in the construction sector has tended to reduce labour productivity growth}

The current economic expansion has been characterised by a shift of labour into the construction sector, both for the Canterbury rebuild, as well as for rising residential construction in Auckland. This domestically focused cycle to date has likely placed downward pressure on aggregate productivity and competitiveness through shifting resources towards less-productive industries. Overall, New Zealand's past productivity growth has tended to be below the OECD average, which reflects a combination of belowaverage within-industry productivity gains and a greater movement of employment towards lowerproductivity industries (Meehan, 2014). For the construction sector in particular, the level of productivity is lower than average, and its growth has been weak compared to other industries, both factors that have helped to lower overall productivity growth.

One factor probably affecting productivity in the construction sector is the small scale of firms. As New Zealand tends to experience more frequent house price cycles with shorter expansion periods than 
many other OECD countries (Bracke, 2013; André, 2010), this may increase planning complexities and builder uncertainty (which could restrict construction), and limit the incentives for firms to grow to scale. Nevertheless, as in other OECD countries, house price expansions have tended to lengthen over time, which may have decreased uncertainty in recent years. In addition, the Canterbury rebuild, which will last for several more years, has also probably provided increased certainty to builders in this cycle. Another issue in New Zealand has been the limited availability of land and preferences for customised designs, which may have reduced incentives for firms to grow. In general, after concerns over skilled labour, construction firms are least happy about local planning and regulation (Figure 14). Therefore, by committing a forthcoming supply of land, such as through the SHAs in Auckland, builders may achieve the lower uncertainty needed for firm expansion. Overall, the relatively low rate of productivity growth compared to best performing countries and other NZ industries may also highlight a continued need to promote training and skills development, including apprenticeships, in the construction sector.

Figure 14. Firms are concerned about skilled labour and the quality of local planning and regulation

Balance of opinion (\% good - \% bad), last financial year at August 20141

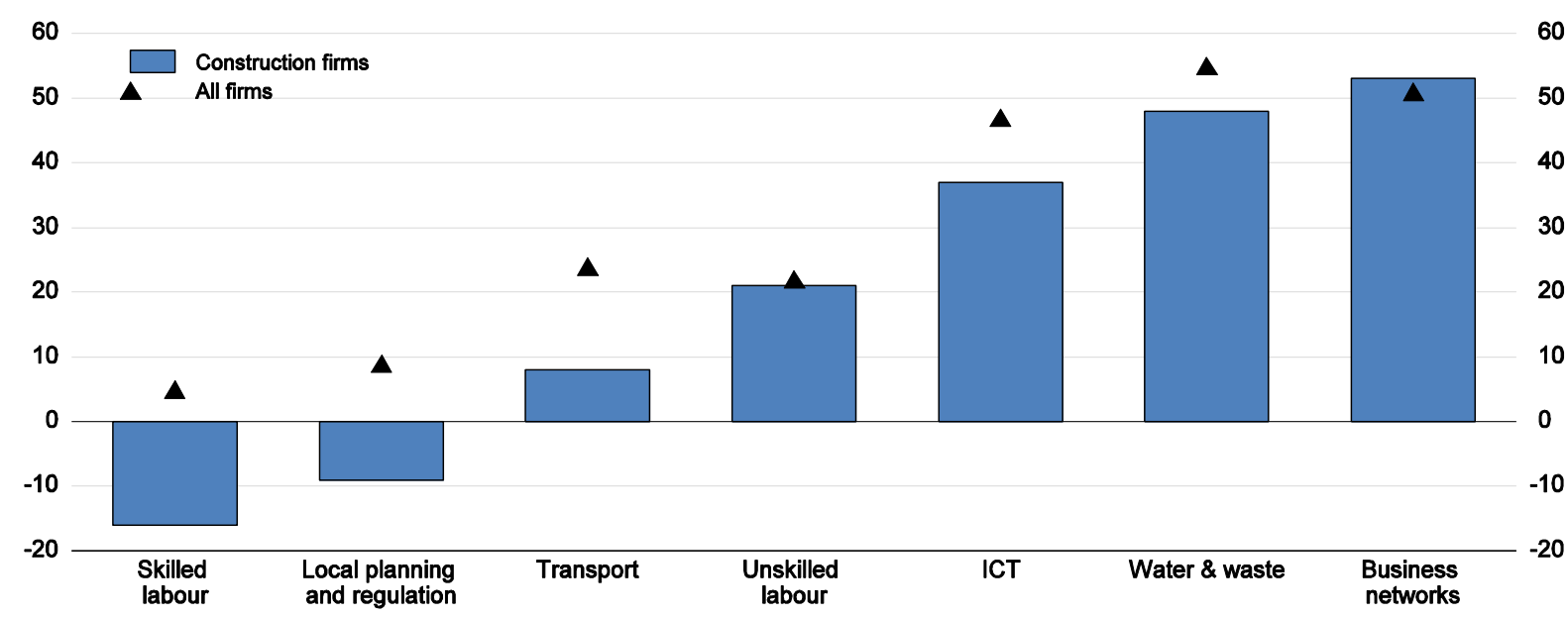

1. Last financial year refers to last financial year for which businesses had results available in August. Financial years for businesses finish on 31 March in New Zealand.

Source: Statistics New Zealand, Business Operations Survey: 2014 and OECD calculations.

\section{Continued attention to reducing housing risks is needed beyond encouraging supply}

On a cross-country basis NZ house prices are high compared to incomes and rents (Figure 10), which may have boosted household debt levels. High house prices and heavy household debt levels (Figure 15) make the NZ economy susceptible to large external shocks. Such a shock could drive a large increase in unemployment, leaving households unable to service their debts, which could in the extreme affect financial stability. Large declines in house prices, which would erode household net worth, could result in lower consumption and overall GDP growth. In addition, a large swing in foreign investor sentiment could cause a sudden stop in the international capital flows that fund a large share of NZ debt, which could also result in financial instability, given the existence of a maturity mismatch between domestic debt, which tends to be for longer durations, and foreign funding, which tends to be at shorter maturities. While NZ banks have built up sizeable buffers to better protect against such shocks, in an environment of global financial uncertainty, the large share of offshore funding makes them vulnerable to increases in risk premiums. This could result in rising borrowing rates and debt servicing costs in New Zealand, which could curtail investment and potential output growth. Although such scenarios are unlikely, given 


\section{ECO/WKP(2015)65}

New Zealand's strong institutions, robust economic performance and progressive increases in core funding ratios since 2010, they are nonetheless another risk that could derail the current expansion.

In October 2013, the Reserve Bank of New Zealand (RBNZ) introduced macro-prudential measures to help to slow the rate of credit and house price increases and reduce financial-stability risks associated with rising house prices. It temporarily placed a $10 \%$ limit on new mortgages with loan-to-value (LTV) ratios greater than $80 \%$ during any three-month period. Given the imbalance in some markets, this policy was also viewed as a way to reduce demand-side pressures to give supply time to catch up so as to limit the extreme peaks in the house price and credit cycle (Rogers, 2014). The RBNZ also increased the amount of capital banks must hold against such high-LTV ratio mortgages.

\section{Figure 15. Household debt in New Zealand}

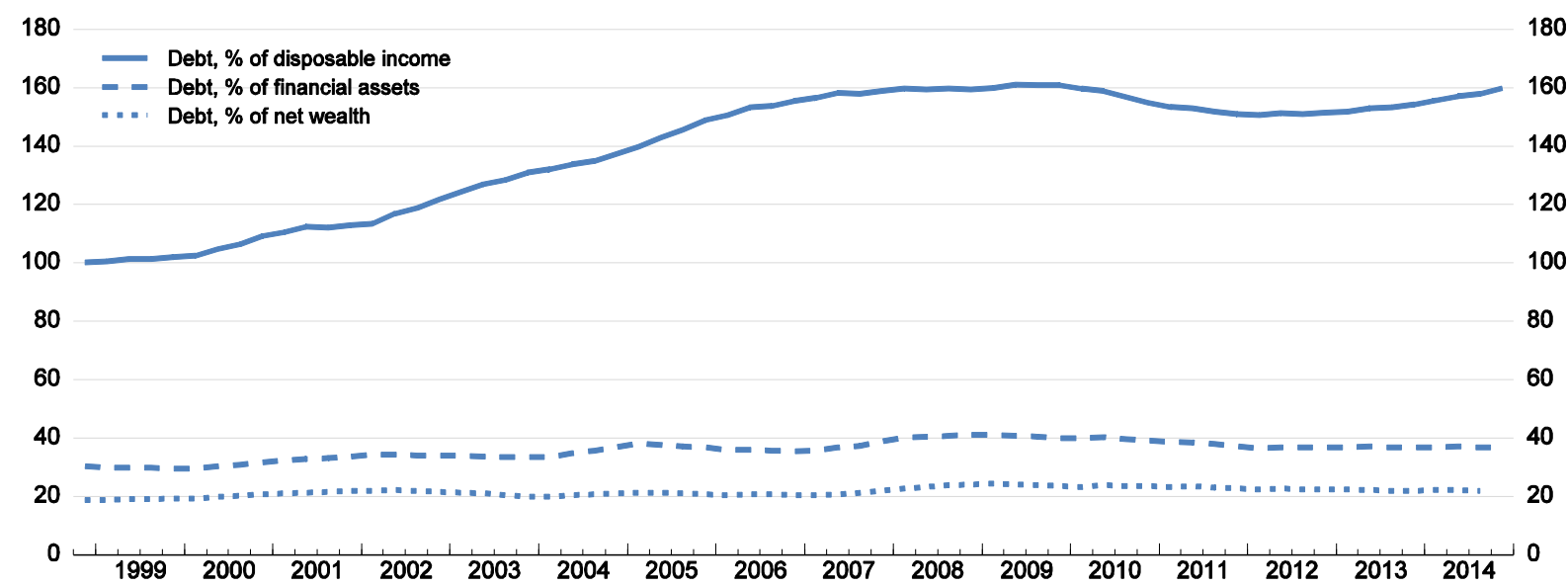

1. Including rental properties.

Source: Reserve Bank of New Zealand, Statistics on Households.

In their first 12 months of operation these measures proved effective in reducing house price inflation and credit growth. While a true counterfactual is unobservable, estimates suggest that this policy may have reduced annual house price growth by 3.3 percentage points and household credit growth by 0.9 point and had a relatively negative impact on house sales as of March 2014 (Price, 2014). Restrictions on LTV ratios tend to be associated with sizeable reductions in housing transactions and slower house price gains, while their effect on restraining credit growth tends to be more moderate (Galati and Moessner, 2014; Igan and Kang, 2011; Cerrutti et al., 2015). Furthermore, these studies show that restrictions on LTV ratios tend to reduce house price growth more than measures focused on lowering debt-to-income or debt-service-to-income ratios, and tend to have a slightly less negative impact on credit growth; however, in both cases the effects are moderate. Macro-prudential instruments are preferable to blunt changes in policy rates because they are more tightly targeted on financial stability objectives and limit additional pressure on the exchange rate and the export sector. Based on estimates presented in RBNZ (2013), a decline in house price growth of this size from the reduction in high-LTV lending would result in weaker household consumption expenditure and would reduce inflation by roughly the same amount as a 30 basis point hike in the policy rate.

The effectiveness of lowering LTV ratio limits may tend to fall through time as lenders circumvent the restrictions (Cerutti et al., 2015; Crowe et al., 2011). For instance, there is a possibility of leakage to non-institutional lenders (such as lending from family members), offshore creditors or non-deposit-taking 
institutions, as the restrictions apply only to registered banks. The RBNZ has implemented additional rules, such as restricting loan top-ups that would push borrowers over the LTV limits, as well as engaging in moral suasion with banks to limit leakage. In addition, allowing $10 \%$ of mortgage loans to have high-LTV ratios and implementing this policy only temporarily may also reduce incentives for unregulated lenders to enter the market, given the uncertainty about the payoffs (Rogers, 2014). To date there has been no evidence of significant leakage, with the possible exception of inter-family lending support.

Lower LTV ratios may have undesirable distributional effects. The burden of lowering LTV limits tends to fall disproportionately on first-time home buyers and poorer individuals. While measures have been increased to offset some of these distributional consequences, these policies may also act to reduce the effectiveness of the LTV restrictions. In particular, house price thresholds for both KiwiSaver Homestart grants (subsidies available for first-time homebuyers who are members of KiwiSaver) and Welcome Home Loans (loans that require lower down payments and are backed by mortgage insurance provided by Housing NZ) were raised as of 1 April 2015 in most regions, and KiwiSaver Homestart grants were doubled in the case a new home (rather than an existing home) was purchased, which may make it relatively more affordable for such households to purchase a home. While Welcome Home Loans present minimal risks to financial stability (Rogers, 2014), they nonetheless lead households to be more susceptible to falling into negative equity positions following a large economic shock that results in house price declines.

The recent doubling of KiwiSaver Homestart grants for new homes only could add additional pressure to already strained construction sectors in some regions by distorting choice. KiwiSaver savings withdrawals for first-time home purchases have been increased to permit the withdrawal of the member tax credit as of 1 April 2015, in addition to all personal and employer contributions. All KiwiSaver savings withdrawals will be permitted for use as an initial deposit on a home as of 1 June 2015, which facilitates purchasing an unconstructed new home. One potential alternative to counter such equity considerations of LTV restrictions would be to ensure that rental properties are a better substitute for homeownership, as discussed in Carey (2015).

Despite these past macro-prudential measures, a resurgence in Auckland house prices since late-2014 has occurred, increasing financial stability risks. As a result, the RBNZ plans to establish a new asset class for residential property lending to investors (defined as any retail mortgage secured on a residential property that is not owner-occupied), as of 1 October 2015, as defaults and loan losses for these types of loans tend to be higher when house prices decline (RBNZ, 2015). From this time, banks will be required to hold more capital against this asset class and investors using bank loans to purchase such residential property will be required to have a deposit of at least 30\% in the Auckland Council area. These measures should help to reinforce the stability of the financial system. To reflect more subdued housing conditions outside of Auckland, additional high-LTV ratio lending (up to 15\% of new loans from $10 \%$ previously) will be permitted in these areas as of 1 October 2015, pending consultation, which should help lessen the distributional consequences of these restrictions outside of Auckland. Also from this time, the government plans to tax gains on residential property sold within two years of purchase (bought on or after 1 October 2015), unless the property is a primary residence, inherited or is part of a relationship property settlement, and to require non-resident purchasers to have an Inland Revenue Department tax number and a NZ bank account. These measures will strengthen enforcement of the tax code in relation to the taxation of trading gains on property and provide information on non-residents' property transactions.

\section{Providing infrastructure to support the economic expansion}

After a period of underinvestment from the 1990s to mid-2000s, non-residential investment has picked up, particularly in the government sector (Figure 16). Nevertheless, some infrastructure shortages remain, namely in Auckland. New Zealand has had relatively low investment in road infrastructure as a 
proportion of GDP (Figure 17). While the level of investment in road projects has increased, which may alleviate some of these shortages, these deficits may have led to perceptions of comparatively low-quality infrastructure (Figure 18), even if some improvements have occurred. Perceived quality is relatively low for road and rail infrastructure relative to local expectations, while port and aviation infrastructure rank favourably compared with other OECD countries (World Economic Forum, 2014). When asked about the most problematic factors for doing business, NZ firms most frequently continue to cite an inadequate supply of infrastructure.

Figure 16. Public and private non-residential construction

As a percentage of GDP

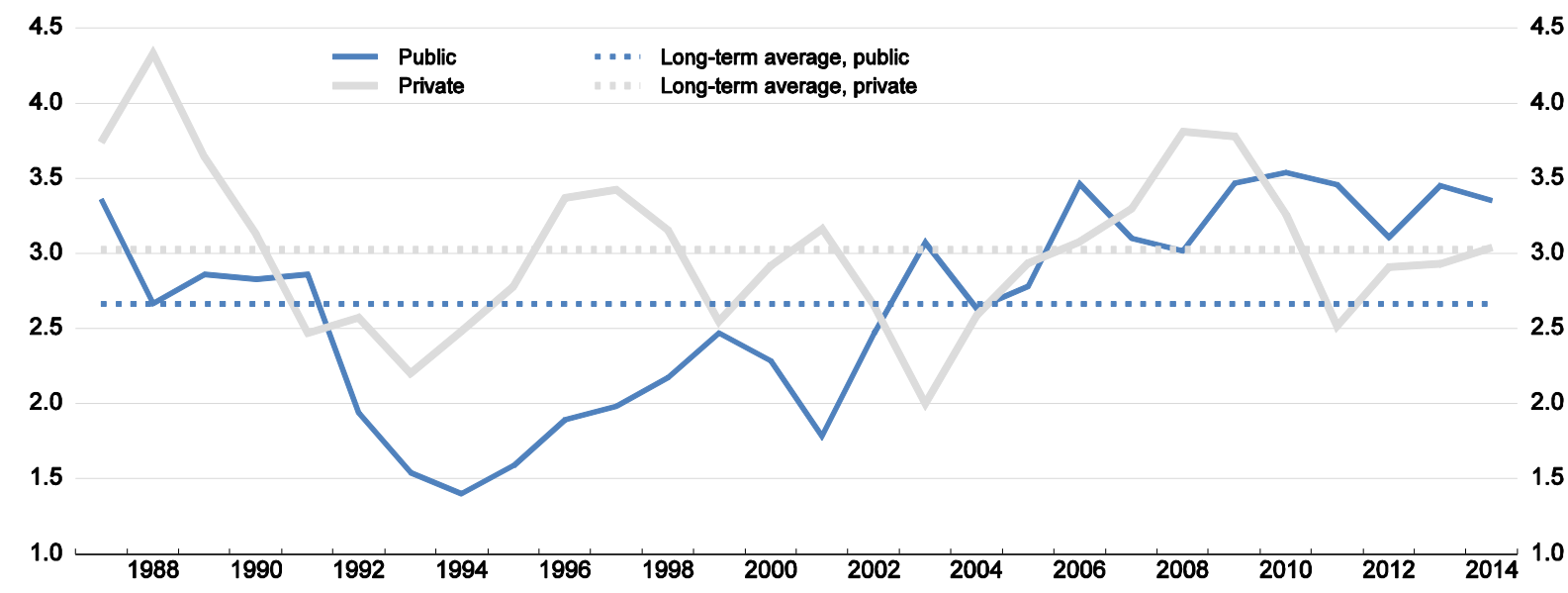

Source: Statistics New Zealand.

Figure 17. Investment in road infrastructure

Average of 2002-11, ${ }^{1}$ per cent of GDP

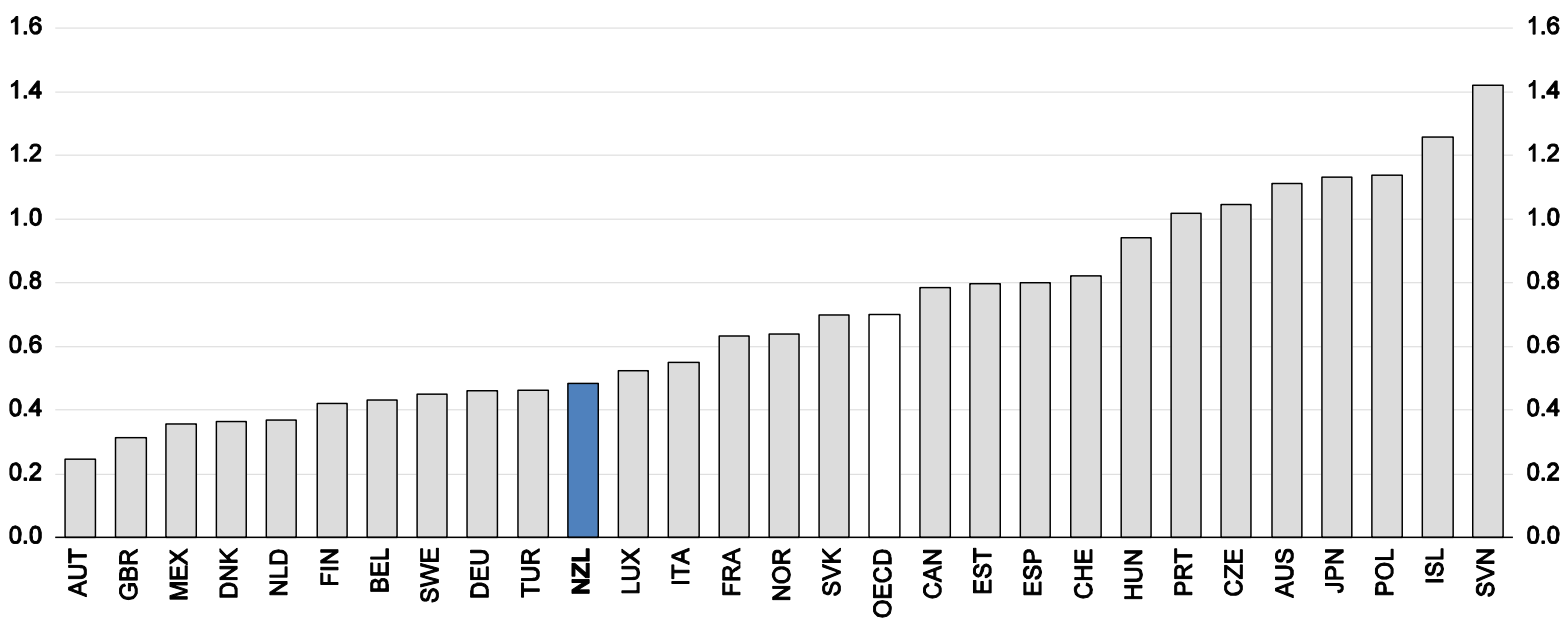

1. Or of the last 10 years available.

Source: OECD, International Transport Forum database. 
Figure 18. Views on quality and supply of infrastructure

\section{A. Perceived quality of overall infrastructure}

Score from 1 to 7 (best)

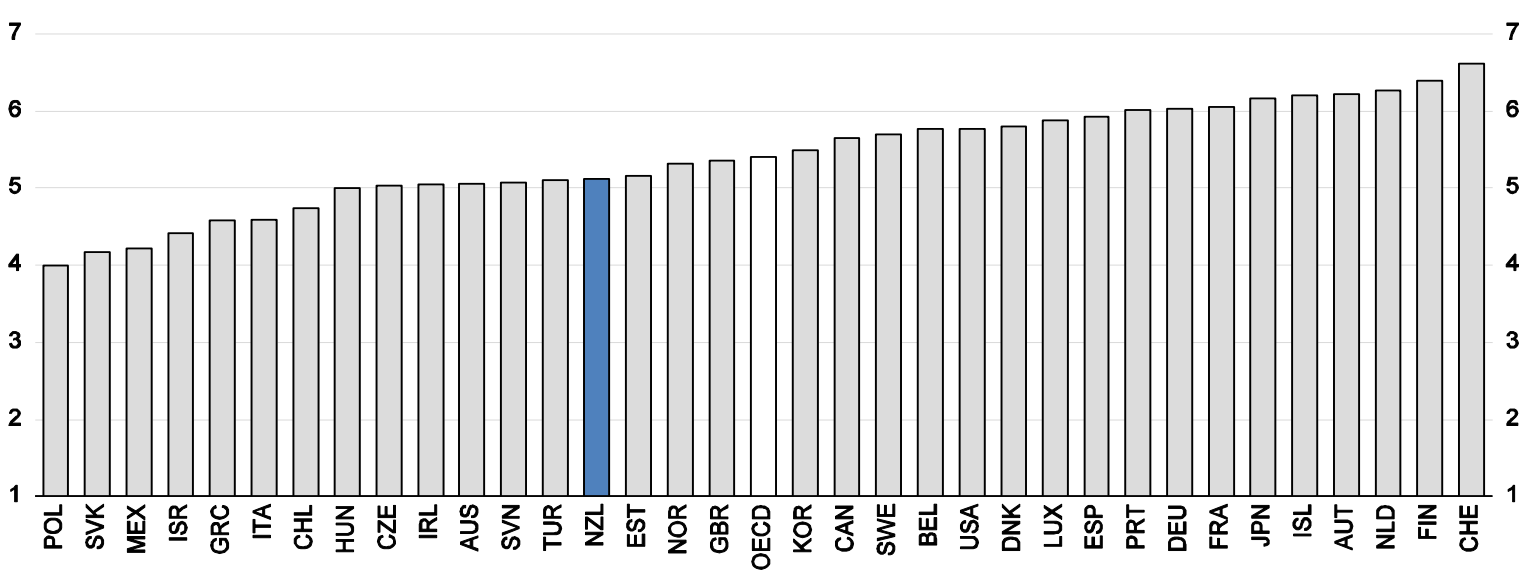

\section{B. Perceived quality of road infrastructure} Score from 1 to 7 (best)

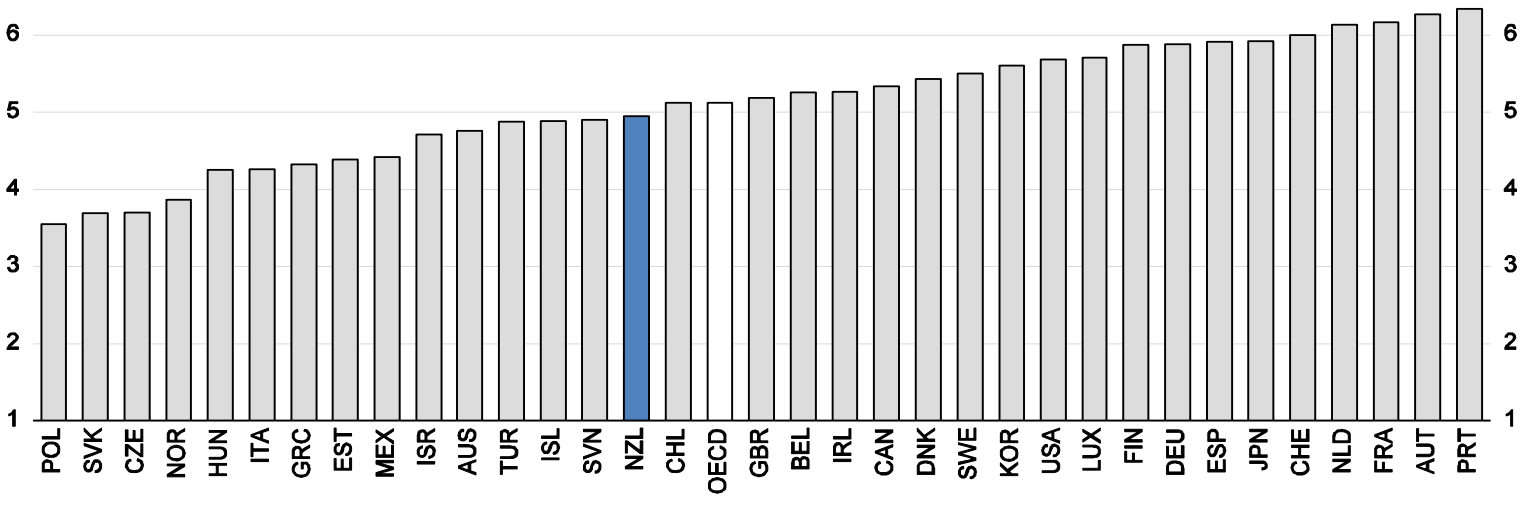

C. The most problematic factors for doing business in New Zealand Per cent of responses

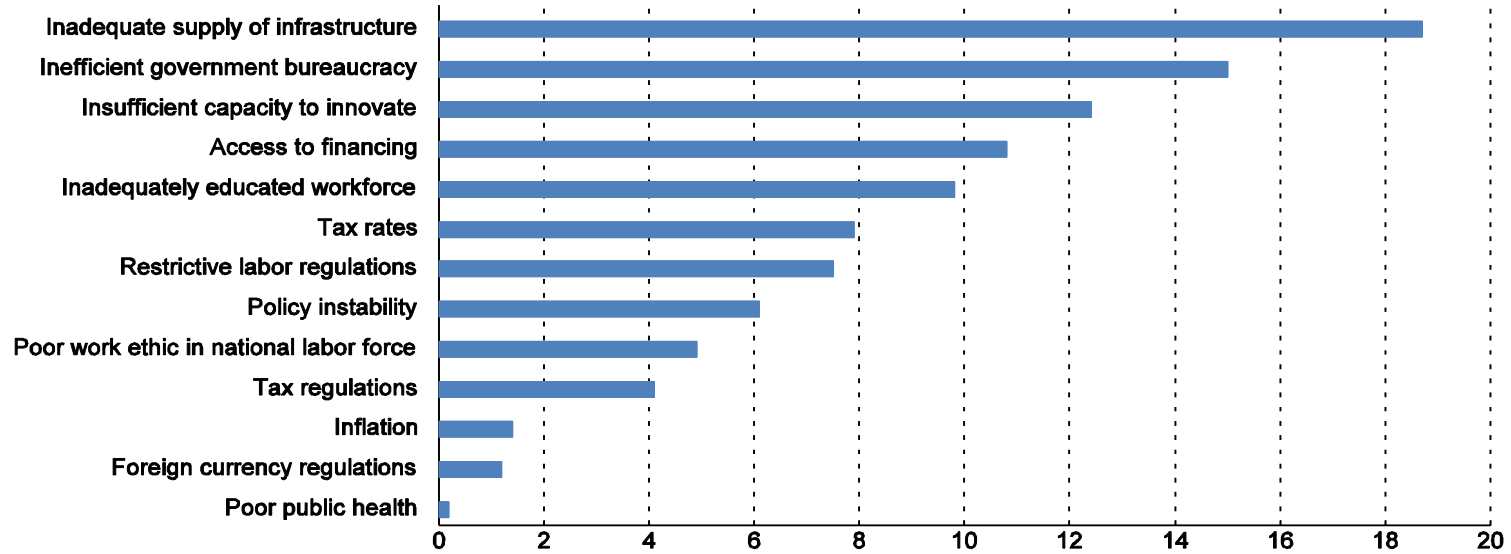

1. Respondents were asked to select the most problematic factors for doing business and to rank them between 1 (most problematic) and 5 . The bars in the figure show the responses weighted according to their rankings.

Source: World Economic Forum (2014), The Global Competitiveness Report 2014-2015. 
Infrastructure is both a concern for the short-run dynamics of the business cycle, as well as the long-term prospects for economic and productivity growth. In the short run, while constraints bind, this may lead to higher production costs and lower overall productivity growth. In the medium to long run, prolonged shortages may deter private investment and erode incentives for firms to locate or remain in New Zealand. Given the pressures on urban infrastructure, particularly on transportation in this cycle, the focus of this section is primarily on urban road infrastructure and public transportation provision; however, in the medium to long run a broader range of infrastructure investments are probably needed to support continued economic growth. In this respect, the establishment of National Infrastructure Plans since 2010 and initiatives to gather evidence and data on infrastructure quality and use (Evidence Base) are positive steps in planning for longer-run infrastructure needs. Continued efforts to collect information on the quality and use of infrastructure where they are currently unavailable, or not transparent, would also aid in future planning. Overall, these initiatives should support increasing coordination between infrastructure sectors and help provide clarity to the private sector regarding infrastructure provision.

\section{Congestion and the variability of travel time remain an issue in large urban areas}

One issue that has arisen in the last few cycles and remains an issue during this expansion, particularly given strong population growth, is road congestion. Driving remains the primary means to get to work in New Zealand, accounting for nearly $80 \%$ of trips, and this share has increased through time (Figure 19). Use of public transportation (bus, trains and ferries) remains low.

Figure 19. Evolution of mode of journeys to work

Full-time workers 6-9:30am, includes combined modes
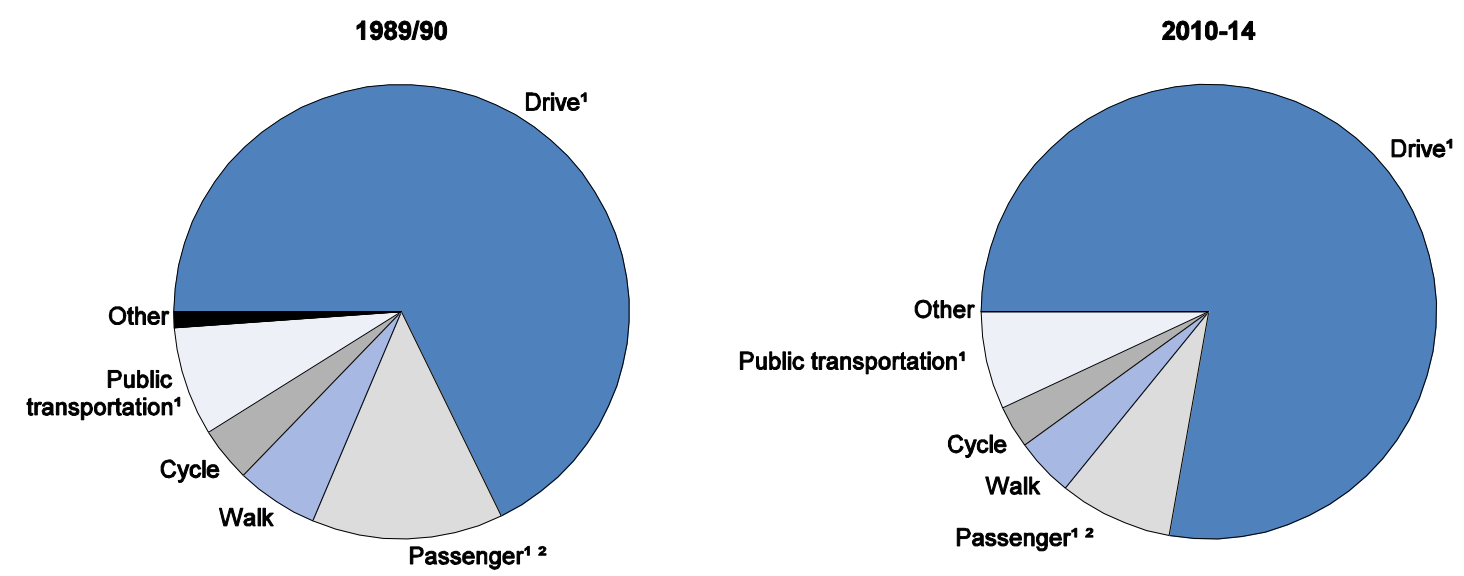

1. And combined modes.

2. Passenger refers to passengers in private vehicles.

Source: Ministry of Transport, New Zealand Household Travel Survey.

Nevertheless, the length of delays appears to have declined since 2009, although a recent deterioration has been noted in 2013 (Figure 20). Over the past 10 years there has been a broad- based increase in capacity utilisation on highways as measured by the number of vehicle kilometres travelled per kilometre of public highway. In recent years, based on this metric, the largest increases have been in the Auckland and Canterbury regions (NIU, 2015). Based on the TomTom traffic index (TomTom, 2015), Auckland and Wellington are considered to be the second and third most congested cities in Australasia, just behind Sydney when considering the ratio of peak to off-peak travel times. This is despite the fact that several Australian cities have higher populations. However, the Beca Travel Time survey (2014) suggests that there may be less congestion in New Zealand than in Australia, although the data are not strictly 
comparable as they are for cities in Australian states instead of for individual cities, as in New Zealand. Congestion is estimated to cost the Auckland region NZD 1.25 billion (NZD 250 million) annually based on comparisons with free flow (full capacity) conditions (Wallis and Lupton, 2013). Beyond congestion, travel predictability is also relatively low in Auckland, particularly during evening peak periods, which may make it difficult for businesses to plan and may reduce the overall well-being of workers.

Figure 20. Road congestion and variability of travel

Average of March and November Surveys
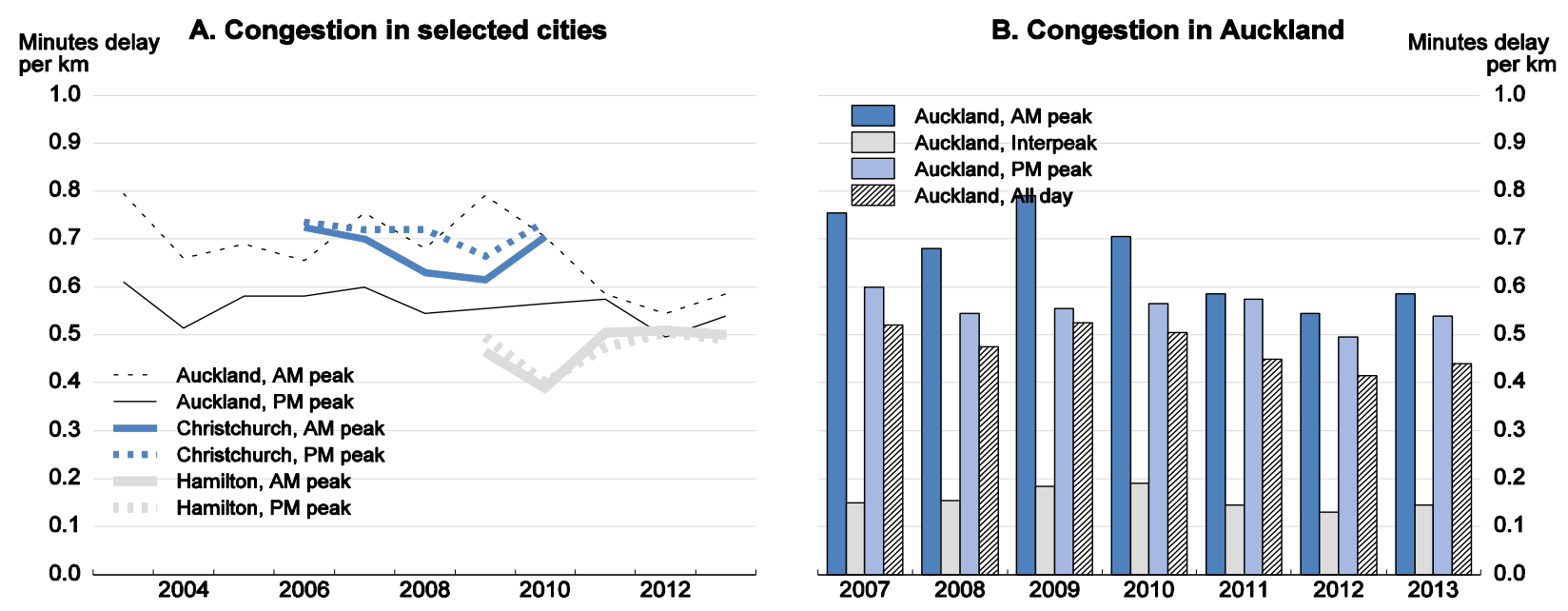

\section{Variability of travel time ${ }^{1}$ in selected cities}

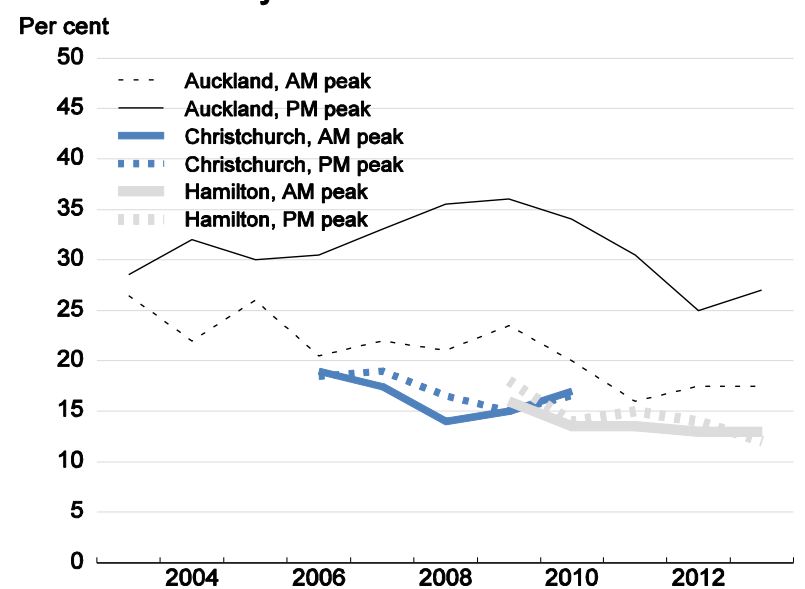

\section{Variability of travel time' in Auckland}

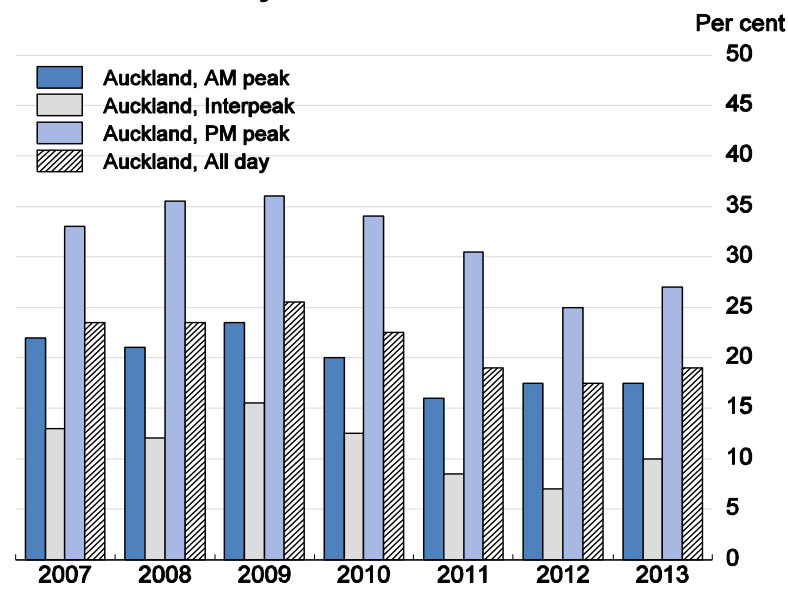

1. Based on the weighted coefficient of variation of travel time on measured roads. Weights on individual roads are based on the amount of travel time on that road as a share of total travel time.

Source: Ministry of Transport.

As highlighted by the New Zealand Treasury (2014b), past underinvestment in road infrastructure, such as highway projects, led to a temporary period of large social returns to such projects. Even if the benefits of investing in roads have probably fallen, reflecting the increased amount of road building, further investment is still likely to bring net benefits. However, ex post cost-benefit analysis (CBA) on past motorway projects in Auckland based on changes in land values have suggested much larger benefits than originally assessed based on ex ante CBA (Grimes, 2008). These benefits may have arisen from increased agglomeration or unforeseen private investments that followed the infrastructure development, as such 
benefits are excluded from CBA. Therefore, there may be a need to assess a broader range of potential benefits from such projects than what is currently incorporated into traditional CBA.

\section{Diversify infrastructure funding by making more use of user-based funding and land value capture}

While there may be net benefits from additional investment in roadbuilding projects, there remains the question of how best to fund them. Given the disproportionate benefit that flows to direct users of local and national roads, user-based funding may better allocate the costs of such developments, and such costs could contribute to better demand management (OECD, 2007). While toll usage has increased in New Zealand, tolls tend to be used only on select, newly developed national highways; however, complementing traditional funding models with such user-pay methods in urban areas, could help reduce financial pressures on local governments of such infrastructure provision. Such charges are equitable in that those who consume infrastructure and services pay for their use; however, there may be some groups disproportionately affected. Therefore, if necessary, the overall tax/transfer system could be adjusted to provide some offset to such charges for disadvantaged groups.

Continuing to explore opportunities for Public-Private Partnerships (PPP) could also provide prospects for efficiency gains and may therefore provide greater value for money compared to traditional procurement (OECD, 2008). Since the National Infrastructure Unit was established in the Treasury in 2009, the number of PPPs has expanded, and more partnerships are being considered, including at local levels, if projects are of sufficient scale, such as in Auckland (Hodges et al., 2013). Over 2012-14, roughly NZD 1.5 billion in PPP projects were initiated in New Zealand (representing roughly $1 \%$ of nominal investment activity, which compares to around NZD 66 billion in Australia (representing roughly $4 \%$ of nominal investment activity) (Drew, 2014), highlighting that New Zealand's level and share of PPP projects in total investment is relatively low but growing. Since the cost of borrowing by the government is lower than for the private sector, there is a need to ensure that such projects bring value-for-money gains or better outcomes and have clearly defined outputs. Affordability considerations also need to take into account the government's intertemporal budget constraints when assessing the ability to pay for the privately provided infrastructure over time.

These value-for-money improvements depend on the extent to which risk is shared between the private and public sector, performance management and output-based specifications are included in PPP contracts, the existence of competition and private sector expertise (OECD, 2008). To date, most projects in New Zealand have involved risk sharing with most PPPs involving the private sector in the design, building, financing and operation and/or maintenance of the infrastructure project, and most have clear outcome targets. As further projects are undertaken, there will be a need to continue to verify that projects provide good value for money and involve adequate risk sharing between the public and private sectors. In addition, ensuring that subsequent monitoring is undertaken, particularly when the PPP is involved in the longer-run provision of public services, can help enable positive outcomes.

Public transportation provision and infrastructure required for new residential developments tend to result in property price increases in the area that is serviced by the new infrastructure; similarly, rezoning land for urban use results in large windfall gains to existing land owners. Therefore, there may be an opportunity for the tax system to capture some of the resulting increased value or rent (e.g. through betterment levies) to pay for required infrastructure (land value capture). In this case, value capture could be used to help fund the broad range of infrastructure needs required to service the new land, develop roads and public transportation and provide schools and other public facilities. While a large share of this has typically been provided by development contributions and through property taxes over time, such contributions can lead to reduced affordability (New Zealand Productivity Commission, 2012). In addition, sharing in a revenue base linked to local economic activity could also enable local governments to reap more of the benefits of population growth. These additional revenue sources could help the Auckland region in particular to fund the infrastructure required by its growing population. 
The amalgamation of Auckland's seven district councils and the regional council into a single unitary authority in 2010 has enabled the region to achieve improved scale and governance to better address infrastructure issues, particularly related to urban water management (OECD, 2015a). Despite this, infrastructure probably remains a constraint on needed housing supply by holding back densification opportunities in Auckland, such as for needed upgrades to storm and waste water infrastructure. Relying more on long-run marginal cost pricing could ensure capacity expansion and future upgrades are adequately factored into the cost. However, this would require increasing water prices, which might be politically difficult. The current focus on short-run marginal costs may also place a relatively large weight on new home developers, through development contributions, to pay for infrastructure in new developments, which contribute in part to eroding affordability. While development contributions have been tightened recently so as to exclude the ability to pay for infrastructure that is not needed to service the residential development (Local Government 2002 Amendment Act 2014), given that the benefits from infrastructure developments extend over several generations, local councils could also consider greater use of debt financing of these costs to promote inter-generational equity and reduce the current burden.

\section{Demand management strategies could encourage a better use of existing infrastructure}

Complementing the additional investments in road infrastructure with better mechanisms to manage the demand on the network is essential to improve efficiency and reduce costs, particularly in Auckland, where the level of congestion and variability of travel times during peak hours is high. Such pricing could better ensure that drivers internalise the marginal social costs they impose on other drivers by entering the network and slowing down their travel times. Placing a cost on travel during peak periods could incentivise drivers to travel at different times (off peak), if they are not required to be on the roads, or could encourage more carpooling and use of public transportation.

There are different methods that could be implemented to charge for congestion, including cordon or zone pricing, or alternative tools that could also deal with congestion, including value-based pricing (or partial facility pricing), full facility pricing or pricing parking. With cordons the focus is on charging for entry or travel in a congested zone. With such pricing mechanisms, public transportation could be used as a lower-quality alternative to car travel. In the case of value-based pricing (or partial-facility pricing), which is more frequently used in the United States, drivers choose whether to drive on higher-quality roads or lanes with less congestion, or use the free, more congested routes. Given heterogeneous consumers, such a policy could be welfare improving. Overall, both cordon pricing or value-based pricing lead to better outcomes than when there is no pricing in place, and value-based pricing could potentially perform better by offering more choice (OECD, 2010). Nonetheless, full-facility pricing schemes, where all lanes are priced and tolls vary based on the time of day, tend to outperform value-pricing schemes in terms of making efficient use of the road network. Alternatively, additional charges on parking could also lead to a reduction in overall congestion as it may lower the number of commuters; however, it may not lead to as strong incentives to alter travel time as would be the case with a true congestion charge.

At the same time, there will be a need for further investments in public transportation, such as rapid transit, to provide more options to commuters who wish to avoid paying the congestion charges. This could also aid in reducing greenhouse gas emissions. In areas that are poorly serviced by public transportation, or where concerns over equity arise (i.e. if costs fall disproportionately on lower-income households), transfers could provide a partial offset of the costs.

\section{Reducing external imbalances}

Continued current account deficits have led to New Zealand's sizeable net international liability position (Figure 21). Despite fluctuating over time, the long-run position has been stable at around $70 \%$ of GDP. Even so banking risks are somewhat reduced by New Zealand's institutions, including a flexible 
exchange rate, which acts as a buffer, and the fact that external loans tend to be denominated in NZ dollars (reducing exchange rate risk) or hedged by NZ banks mitigates the risks. In addition, as previously mentioned, capital ratios have been progressively increased, also making banks more resilient to potential shocks. However, in an environment of global financial uncertainty, the large share of offshore funding makes NZ banks vulnerable to changes in investor sentiment and increases in risk premiums.

Figure 21. Net international investment position

Average 2009-13, as a percentage of GDP

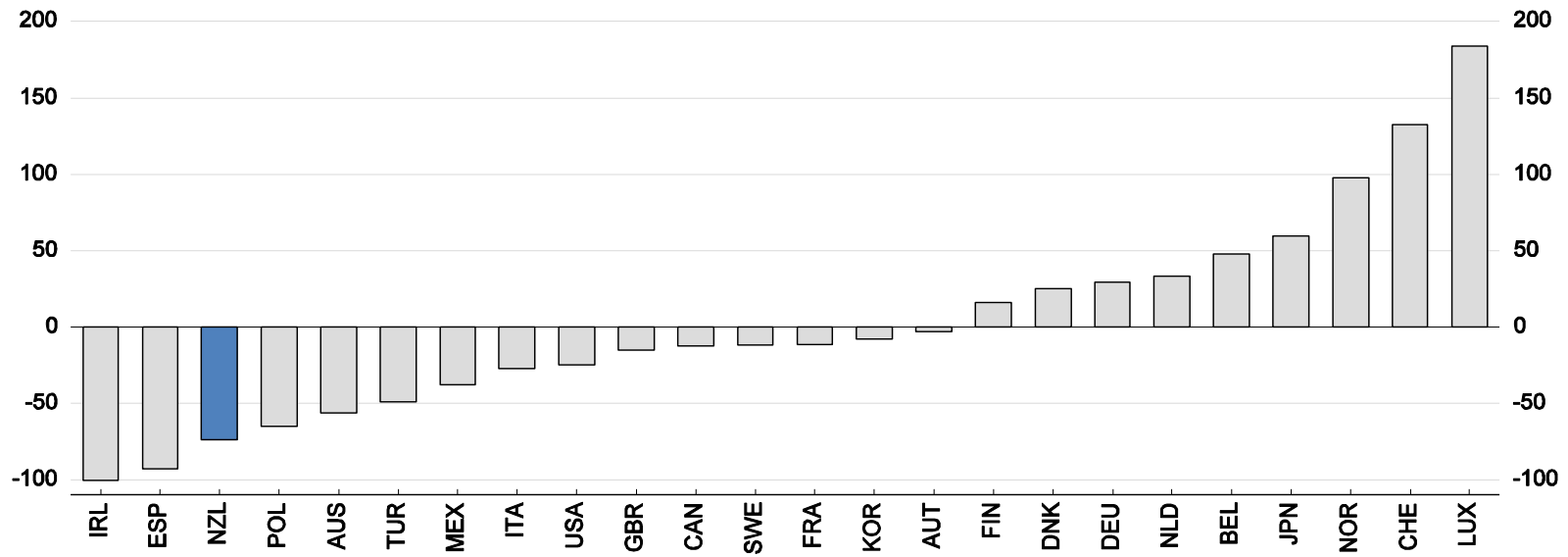

Source: IMF, International Investment Position database for net international investement position for all countries except New Zealand (Statistics New Zealand for net international investment position and OECD, Economic Outlook 96 database for GDP data).

As shown by Cheung (2013) in a cross-country analysis, there is a significant (positive) long-run relationship between the level of net foreign liabilities and the level of interest rates. Therefore, the NZ position may result in higher funding costs than otherwise, which may dampen private investment and exports through the positive impact that interest rates have on capital inflows to fund debt, bidding up the exchange rate. While the main cause of New Zealand's low share of exports in GDP is likely to be its distance to markets, which limits its participation in global value chains (de Serres et al., 2014), the trend appreciation of the effective exchange rate since 2000 has also probably played a role, resulting in a falling export share (Figure 22). Therefore, efforts to improve the external balance through higher saving could help not only to reduce external risks to growth, but also to aid in a longer-run rotation of demand towards interest-sensitive, higher value-added activities such as exports and business investment.

These external imbalances reflect a lack of national saving rather than a large volume of investment compared to other OECD countries (Figure 23). It is private saving that is especially low, while investment as a share of GDP is around the OECD median (Figure 24), despite a different composition: business investment is relatively weak in New Zealand, while public investment as a share of GDP is higher than in comparator countries. While this combination might be detrimental to productivity, the main culprit behind the persistent current account deficits has been low saving. 
Figure 22. Share of exports

Per cent of GDP

\section{A. Average 2005-14}

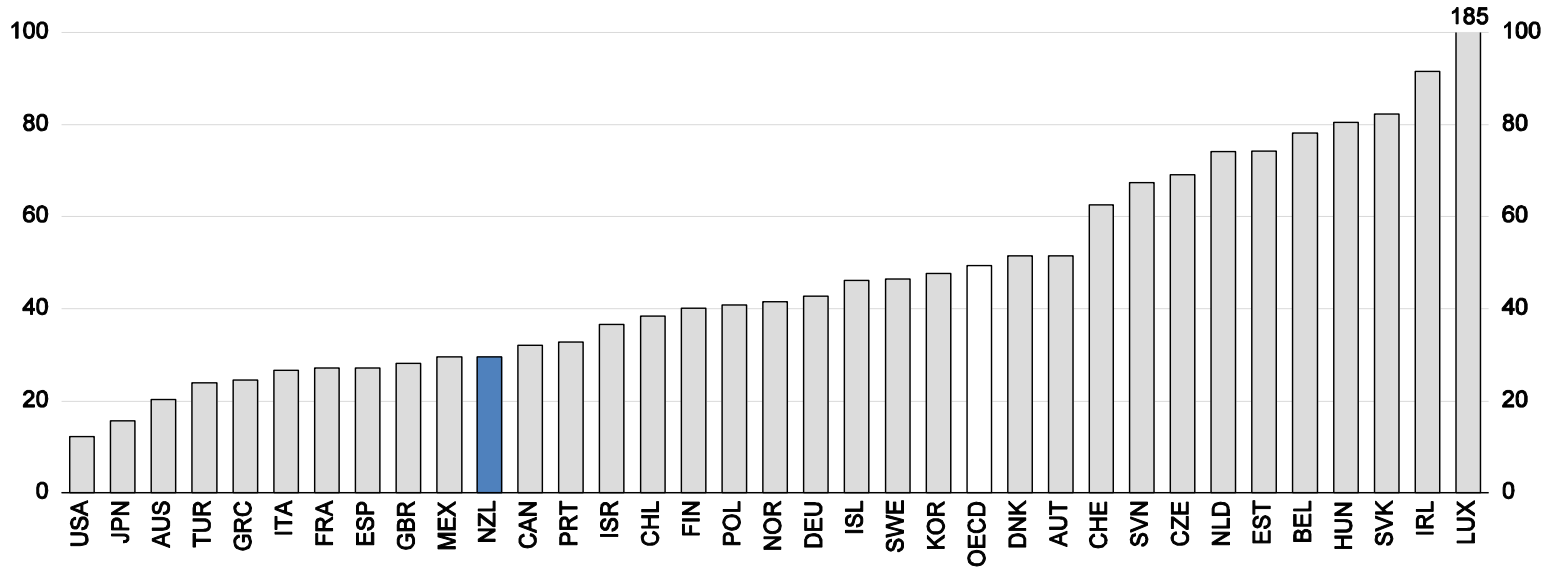

B. Change in export share between 2000 and 2014

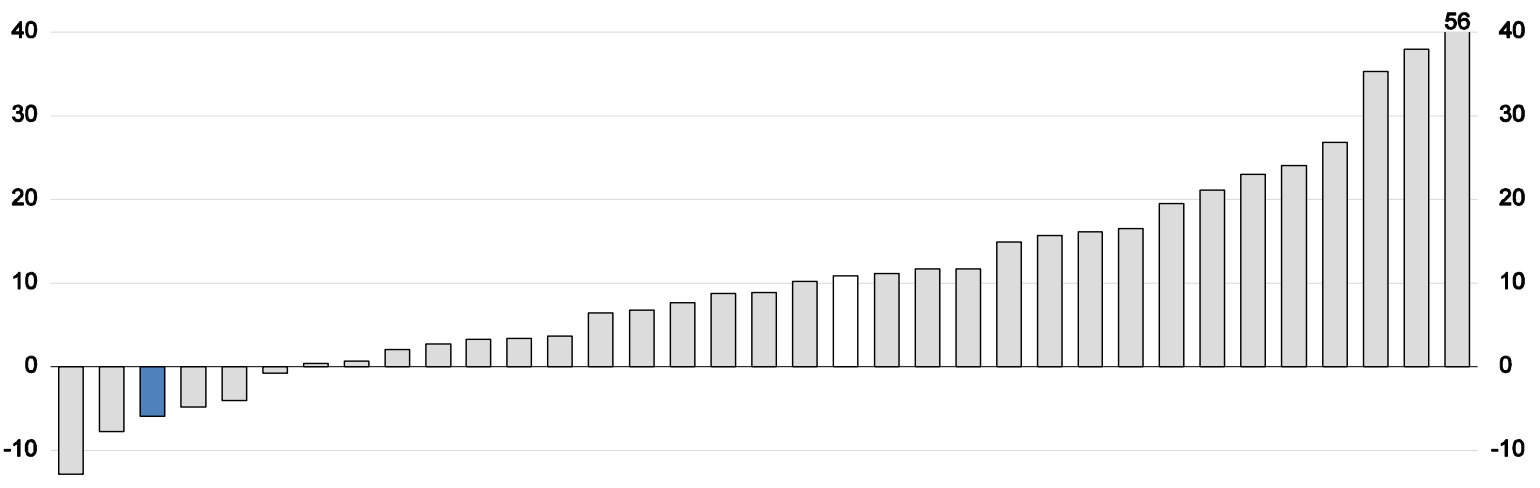

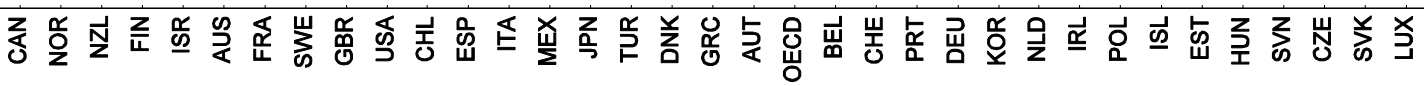
Source: OECD, Economic Outlook database.

Figure 23. Net saving rates ${ }^{1}$

Average $2004-13,{ }^{2}$ per cent of GDP

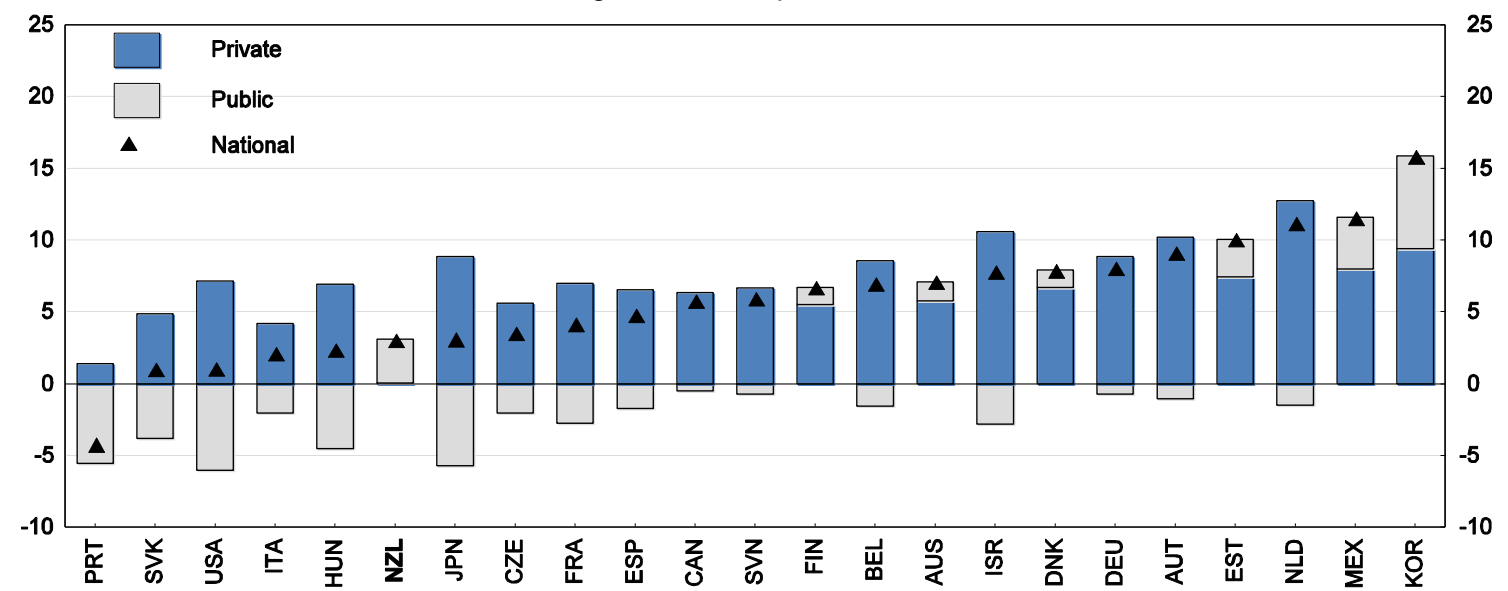

1. Gross saving adjusted for depreciation.

2. Or last 10 years available.

Source: OECD, National Accounts database and Economic Outlook database. 
Figure 24. Investment rates ${ }^{1}$

Per cent of GDP
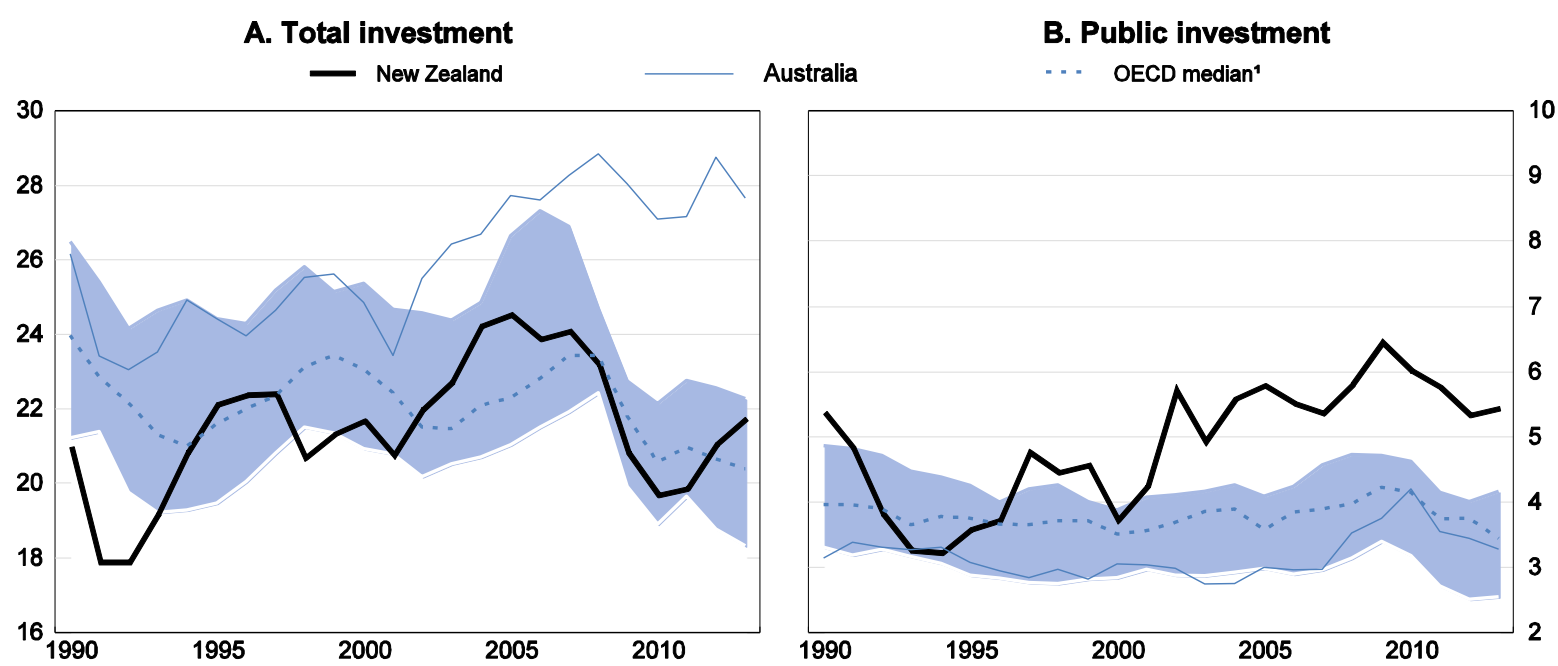

C. Residential investment

D. Private non-residential investment
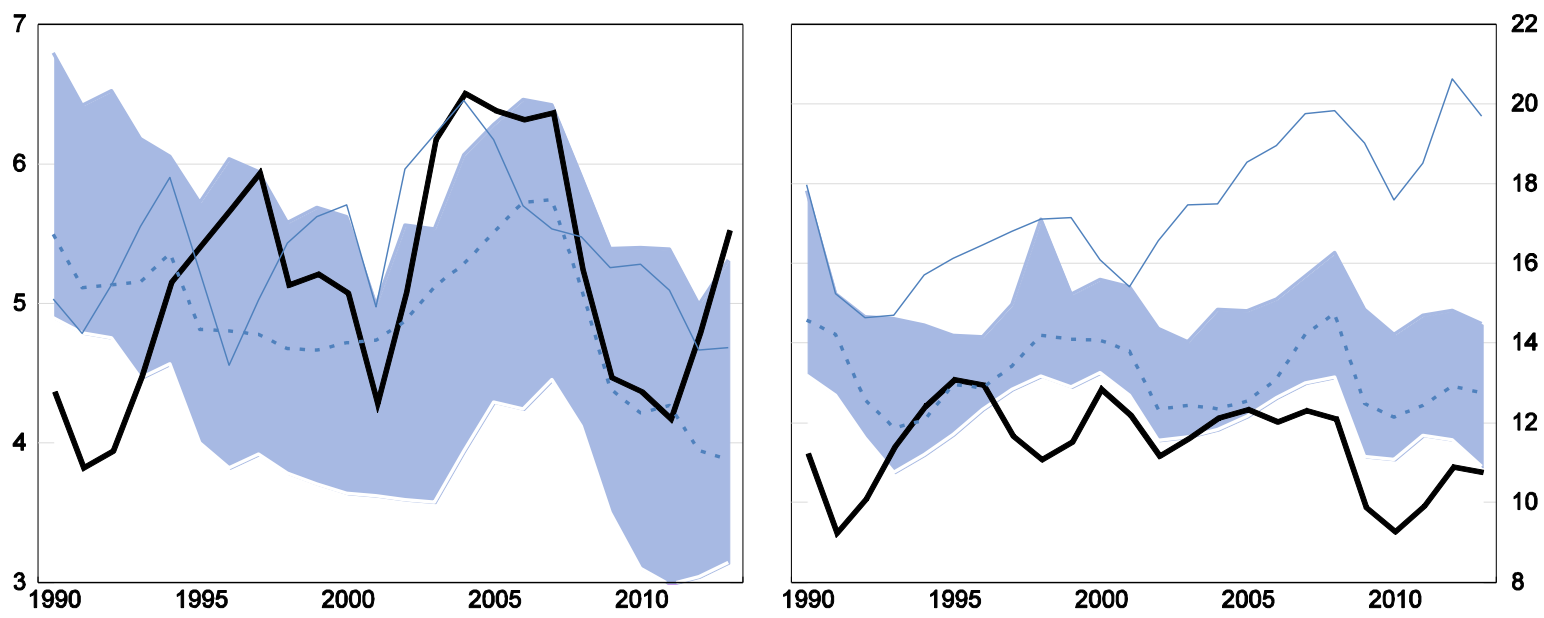

1. The shaded area is the range of OECD countries from 25th to 75 th percentile. Half of the countries lie inside this range. Source: OECD, Economic Outlook database.

\section{Higher private saving rates could help to reduce external liabilities}

Although private saving rates are undoubtedly low, there is a lack of consensus over the causes as well as the potential policy responses. One explanation frequently cited is that the welfare system, including comparatively low out-of-pocket health-care expenditures (OECD, 2014b) and a generous firsttier pension scheme, particularly for lower income individuals, may be reducing incentives to save for retirement (though their savings are generally modest). In addition, New Zealand is one of only two OECD countries that do not have a mandatory second-pillar pension scheme and also do not have tax incentives in place to encourage long-term saving (beyond capped tax credits available through KiwiSaver); however, equity investments do receive somewhat more favourable tax treatment, as capital gains are not taxed (dividends are taxed, although New Zealand's imputation tax system ensures they are not double-taxed). While there is mixed evidence on the extent to which tax incentives can induce higher net new saving, 
most studies point to some positive impact (e.g. Poterba et al., 1995/1996; Ayuso et al., 2007; Gelber, 2011; Attanasio and DeLeire, 2002).

Although the low level of private saving (which is related to weak household saving rates) looks worrisome at a macro level, at a micro level such concerns are less clear. Past studies have shown that NZ households are generally able to smooth their consumption into retirement, suggesting that saving may be sufficient for the majority of such units (Le et al., 2009). Nonetheless, saving levels may become more of a concern for younger generations who may have lower homeownership levels than their forbears if they are not saving through other means and also have higher levels of debt when they finish their education. Household saving rate measures constructed from micro and macro stock data, which are based on changes in net wealth excluding revaluation effects (otherwise known as active saving), suggest a higher rate of household saving over history (Gorman et al., 2013). Furthermore, NZ household saving rates based on flow measures of income and outlays from the national accounts have tended to be revised up over time (Gorman et al., 2013). As a result household saving may be less of a concern than what the aggregate measures suggest, particularly regarding the adequacy of retirement saving.

This said, there may still be a need to increase saving to reduce the risks from external imbalances. One beneficial reform could be to correct the distortion inherent in the inflation bias in the tax system. In particular, taxing nominal income from savings at the top marginal rate in the presence of inflation magnifies the bias towards current consumption. Therefore, measures to raise returns directly by adjusting for this inflation bias or lowering the tax rate on long-term saving, as mentioned above, could improve overall saving rates. In addition, several studies have pointed out that automatic enrolment in voluntary saving schemes tends to boost saving rates (e.g. OECD, 2014c). This lies behind the automatic-enrolment feature of KiwiSaver for new employees. Therefore, there may be a benefit to extending automatic enrolment to existing employees. Moving further towards a compulsory saving scheme, by, for example, making KiwiSaver more like a second-pillar pension scheme, could also raise private saving. Such a scheme would encourage more participation from lower-income groups and liquidity-constrained individuals who generally have a low propensity to save, though their welfare might be maximised by consuming more at present, despite relative poverty later on.

Higher NZ house price appreciation appears to be associated with lower household saving rates (Figure 25), and countries with faster house price rises appear to have smaller increases (or a decline) in their current account balance, which may reflect weaker saving. Several studies have supported the view that higher house prices and the resulting increase in household wealth have lowered private saving (IMF, 2011; Jarrett, 2011). Therefore, implementing measures to make housing supply more responsive to demand may also help to increase the aggregate amount of household saving in the longer run by limiting capital gains on housing. Overall, ensuring that the financial system remains sound and funding and liquidity buffers high is paramount to preventing fluctuations in the quantity and price of external funding from harming the financial sector and real activity. 
Figure 25. Real house prices and the dynamics of saving and current account balances

\section{A. Real house price growth and household saving ratio developments in New Zealand}

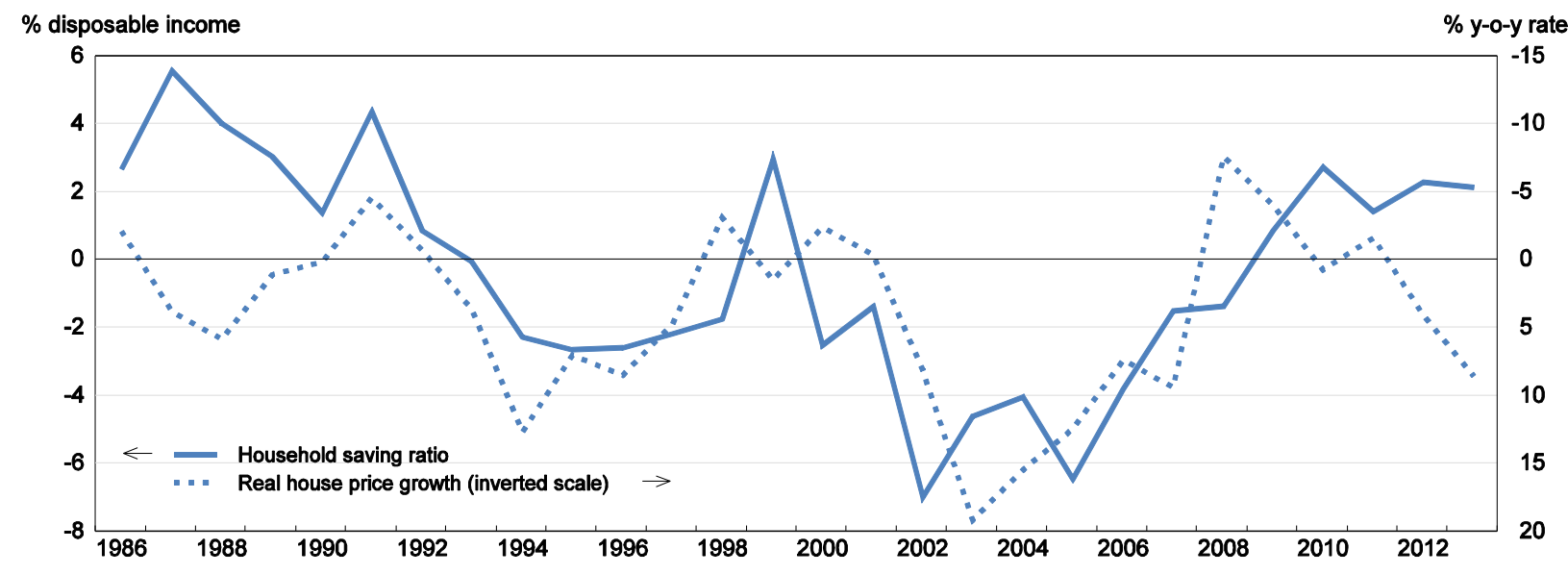

B. Real house price growth and current account balance

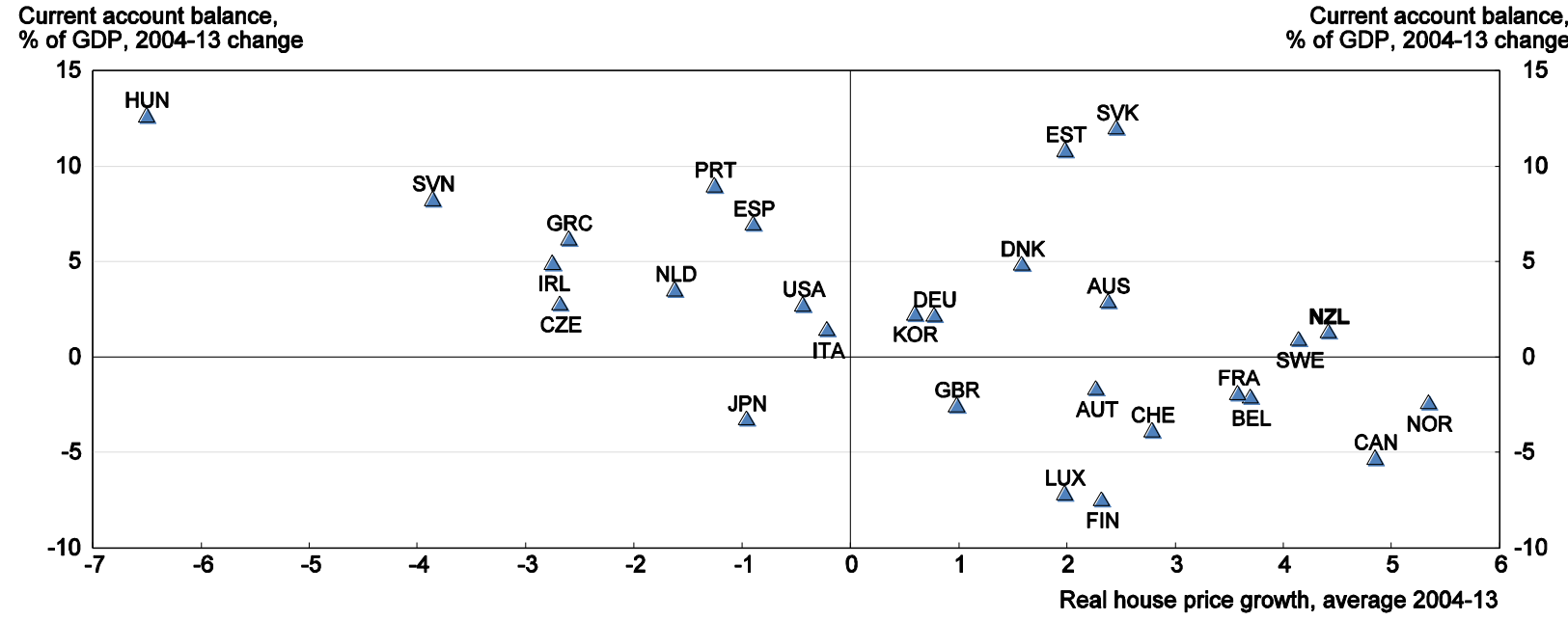

Source: OECD, Economic Outlook and House Price databases.

\section{Public saving and the sustainability of fiscal policy}

While the NZ government's debt level is relatively low, it has increased since the global financial crisis (GFC) and the Canterbury earthquakes. The government is aiming to bring net core crown debt back to 20\% of GDP by 2020 from 26\% of GDP at present (New Zealand Treasury, 2014a). As highlighted by Ding et al. (2014), countries that have made substantial progress in reducing elevated levels of net foreign liability have generally done so through deliberate measures to increase gross public saving. Boosting public saving as currently planned will enhance New Zealand's longer-run fiscal sustainability, particularly in the face of rising ageing-related pension and health-care expenditures. Furthermore, a strong fiscal position is appropriate in New Zealand as the country faces potentially large macroeconomic shocks, given its external imbalance and volatility in export revenues, particularly related to dairy prices. If the economy performs better than expected, it may be appropriate to consolidate faster by saving revenue surprises, particularly if proven to be temporary in nature, which would also serve to raise national saving. 
While net debt levels can be reduced both by paying back gross debt or by accumulating assets, given that gross debt appears to be more relevant for financial markets (Price et al., 2008), public saving should be focused initially on reducing gross debt to achieve target net debt levels so long as reasonable liquidity is maintained in individual bond issues, as is currently planned. Restarting contributions to the New Zealand Superannuation Fund, once net debt reaches target levels, as is envisaged, will also help to finance future ageing-related liabilities.

During several economic upturns fiscal policy was expansionary in New Zealand (Ter-Minassian, 2014; Brook, 2013), which may have added to demand pressures and inflation, resulting in higher policy rates than would have otherwise been the case. This would be particularly detrimental if permanent tax cuts or spending increases are implemented in the face of temporary favourable revenue surprises. During expansions there also appears to be a stronger cross-country association between fiscal policy changes and the current account. This may result from higher imports related to budget expenditures when the output gap is positive and the positive impact fiscal expansion has on interest and exchange rates (Abbas et al., 2010), which may further exacerbate external imbalances. Higher interest rates probably contributed to the appreciation of the NZ dollar during the latter part of the last upturn in 2005-08 when fiscal policy was expansionary (Brook, 2013). Such pressures may have damaged the competitiveness of the tradables sector, constraining exports, and may have crowded out private investment.

In New Zealand the Public Finance Act (PFA) sets the principles for responsible fiscal management and conduct. Regular reporting by the government is required as to the extent that fiscal policy is consistent with these principles. The PFA also requires regular and independent economic and fiscal updates by the Treasury. While these principles include a focus on sustainability in the conduct of fiscal policy, 2013 amendments to the PFA also require the government to consider the interaction of fiscal with monetary policy when formulating its fiscal strategy, which should improve fiscal policy coordination with the economic cycle. However, political economy considerations and electoral cycles are likely to continue to favour spending and tax cuts during expansions, since there are no sanctions for breaching the PFA's provisions.

An independent fiscal council (IFC) could analyse fiscal policy settings in the context of the economic cycle to help to counter these spending pressures by generating greater public awareness of their longer-term burden, particularly since public engagement in fiscal policy is relatively low in New Zealand (Petrie, 2013). Political economy issues can arise both due to the common pool problem, where the incumbents seeking re-election increase the provision of public goods or services or tax breaks to their own constituents without internalising the costs, and through the time-inconsistency of policy, where short-run gains could lead to sub-optimal fiscal plans. One role of an IFC could be to highlight these inconsistencies, increase transparency and provide more information to the public about the stance of fiscal policy, thereby reducing incentives for such manoeuvring. The number of fiscal councils in OECD countries has grown, with their mandates differing depending on the country's political structure. Some IFCs are involved in providing budget forecasts or projections of budget inputs, implementing and/or monitoring the compliance with fiscal rules, providing cost estimates for various spending or tax measures and providing other positive or normative analyses. Given the Treasury's independence in producing fiscal projections and policy advice, an IFC in New Zealand could have a more limited remit, such as providing normative analysis and advice on the stance of fiscal policy and plans, particularly regarding the sustainability of the fiscal strategy, thereby requiring fewer resources than in some other countries. A focused mandate on assessing fiscal policy is characteristic of smaller IFCs, such as the Irish Fiscal Advisory Council (Debrun and Kinda, 2014). Empirically, fiscal councils are associated with greater fiscal discipline, provided they have certain characteristics, such as political independence and high media impact (Debrun and Kinda, 2014; Hagemann, 2011). 


\section{Recommendations for sustaining the economic expansion}

\section{Continue to increase the dynamism of the labour market and reduce skills shortages}

- Draw lessons from the Canterbury Skills and Employment Hub (a labour-market matching scheme), trial it elsewhere and, subject to positive results, roll it out country-wide.

- $\quad$ More frequently update immigration skills shortage categories to reduce labour market bottlenecks.

- $\quad$ Make English-language requirements in the immigration process stricter, or provide additional English language training and follow-up to facilitate immigrants' labour market integration.

- Continue to provide and better centralise information on returns to education by field of study to better guide student choice.

Improve housing supply responsiveness

- Provide guidance to regional authorities in the implementation of environmental and planning regulations, including the Resource Management Act. Reduce their economic costs and the scope for vested interests to limit competition or thwart rezoning and development that would be in the wider public interest.

- $\quad$ Better equip local councils through increased resources and training to undertake the urban planning process.

\section{Continue to develop infrastructure}

- Implement infrastructure demand management strategies to reduce urban road congestion, notably congestion charging. Consider diversifying revenue sources for local infrastructure funding, such as sharing in a revenue base linked to local economic activity or taxing the windfall gains that accrue to landowners from rezoning land for urban use.

- $\quad$ Continue to pursue Public-Private Partnerships where they provide good value for money and may lead to greater efficiencies and better outcomes, while ensuring that risks are adequately shared between the private and public sectors.

\section{Encourage higher private saving}

- $\quad$ Expand automatic enrolment in KiwiSaver to existing employees.

\section{Further enhance fiscal sustainability}

- Implement fiscal consolidation measures to reduce net core crown debt as planned, while continuing efforts to improve the well-being of the most vulnerable members of society. Allow the automatic stabilisers to operate fully.

- Create an Independent Fiscal Council, focused on providing policy advice and analysis on the fiscal stance, with a special emphasis on monitoring sustainability and coordination with the economic cycle. 


\section{Bibliography}

Abbas, S.M.A., J. Bouhga-Hagbe, A.J. Fatás, P. Mauro and R.C. Velloso (2010), "Fiscal Policy and the Current Account", IMF Working Paper 10/121, May.

André, C. (2010), “A Bird's Eye View of OECD Housing Markets”, OECD Economics Department Working Paper, No. 746, OECD Publishing.

Auckland Council (2012), Housing Action Plan - Stage 1, December.

Auckland Council (2013), Housing Matters: Chief Economist's Newsletter, December.

Auckland Council (2014), Auckland Economic Quarterly, July.

Attanasio, O. and T. DeLeire (2002), "The Effect of Individual Retirement Accounts on Household Consumption and National Saving", The Economic Journal, Vol. 112, July.

Ayuso, J., J. Jimeno-Serrano and E. Villanueva (2007), “The Effects of the Introduction of Tax Incentives on Retirement Savings", Banco de España Research Paper, No. 0724, February.

Bloom, N., C. Genakos, R. Sadun and J. van Reenen (2012), "Management Practices Across Firms and Countries", Academy of Management Perspectives, Vol. 26. No. 1.

BNZ (2015), Auckland Housing Shortage is How Big?, April.

Bracke, P. (2013), "How Long Do Housing Cycles Last? A Duration Analysis for 19 OECD Countries", Journal of Housing Economics, September, Vol. 22. No. 3.

Brook, A.-M. (2013), "Making Fiscal Policy more Stabilising in the Next Upturn: Challenges and Policy Options", New Zealand Economic Papers, Vol. 47. No. 1.

Caldera, A. and A. Johansson (2013), "The Price Responsiveness of Housing Supply in OECD Countries", Journal of Housing Economics, Vol. 22. No. 3, September.

Carey, D. (2015), “Making New Zealand's Economic Growth More Inclusive”, OECD Economics Department Working Papers, forthcoming.

Cerutti, E., S. Claessens and L. Laeven (2015), “The Use and Effectiveness of Macroprudential Policies: New Evidence", IMF Working Paper 15/61, March.

Cheung, C. (2011), "Policies to Rebalance Housing Markets in New Zealand", OECD Economics Department Working Papers, No. 878, OECD Publishing.

Cheung, C. (2013), "Policies to Support Sustainable Long-Term Growth in New Zealand", OECD Economics Department Working Papers, No. 1076, OECD Publishing.

Crowe, C., G. Dell'Ariccia, D. Igan and P. Rabanal (2011), "How to Deal with Real Estate Booms: Lessons from Country Experiences", IMF Working Paper 11/91, April. 


\section{ECO/WKP(2015)65}

Debrun, X., and T. Kinda (2014), "Strengthening Post-Crisis Fiscal Credibility: Fiscal Councils on the Rise - A New Dataset", IMF Working Paper 14/58, April.

Demographia (2015), $11^{\text {th }}$ Annual International Housing Affordability Survey: 2015.

Department of Labour (2011), "Labour Market Adjustment in the Construction Industry, 2001-2009", Department of Labour, Wellington.

Ding, D., W. Schule and Y. Sun (2014), "Cross-Country Experience in Reducing Net Foreign Liabilities: Lessons for New Zealand", IMF Working Paper 14/62, April.

Docquier, F., Ç. Ozden and G. Peri (2014), "The Labour Market Effects of Immigration and Emigration in OECD Countries", The Economic Journal, Vol. 124, September.

Drew, A. (2014), "Funding the World's Most Liveable City: The Missing Third Leg?", NZIER Insight 492014, November.

Egert, B. and R. Kierzenkowski (2010), "Exports and Property Prices in France: Are They Connected?", OECD Economics Department Working Papers, No. 759, OECD Publishing.

Fry, J. (2014), "Migration and Macroeconomic Performance in New Zealand: Theory and Evidence?", New Zealand Treasury Working Paper, 14/10, April.

Galati, G. and R. Moessner (2014), "What Do We Know About the Effects of Macroprudential Policy?", DNB Working Paper, No. 440, September.

Gelber, A. (2011), "How do 401(k)s Affect Saving", American Economic Journal: Economic Policy, Vol. 3, No. 4, November.

Glaeser, E., J. Gyourko and A. Saiz (2008), "Housing Supply and Housing Bubbles”, NBER Working Paper, No. 14193, July.

Gorman, E., G. Scobie and Y. Paek (2013), "Measuring Saving Rates in New Zealand: An Update", New Zealand Treasury Working Paper 13/04, February.

Grimes, A. (2008), “The Role of Infrastructure in Developing New Zealand's Economy”, Motu Note, Wellington.

Grimes, A. and A. Aitkens (2010), "Housing Supply, Land Costs and Price Adjustment", Real Estate Economics, Vol. 38, No. 2, Summer.

Grimes, A. and Y. Liang (2007), "Spatial Determinants of Land Prices in Auckland: Does the Metropolitan Urban Limit have an Effect", Motu Working Paper, No. 07-09, Wellington.

Grimes, A. and I. Mitchell (2015), "Impacts of Planning Rules, Regulations, Uncertainty and Delay on Residential Property Development”, Motu Working Paper, No. 15-02, Wellington, January.

Gyourko, J. and R. Molloy (2014), "Regulation and Housing Supply", NBER Working Paper, No. 20536, October.

Hagemann, R. (2011), “How Can Fiscal Councils Strengthen Fiscal Performance?”, OECD Journal: Economic Studies, Vol. 2011/1. 
Hodges, G., L. Proctor and B. King (2013), "Mayoral Position Paper on Public Private Partnerships", Auckland.

Igan, D. and H. Kang (2011), "Do Loan-to-Value and Debt-to-Income Limits Work? Evidence from Korea”, IMF Working Paper 11/297, December.

IMF (2011), New Zealand Selected Issues, April, Washington.

Jarrett, P. (2011), "Housing, the New Zealand Business Cycle and Macroeconomic Imbalances", Presentation to a Reserve Bank and New Zealand Treasury Workshop on Macroeconomic Imbalances, Wellington.

Koźluk, T. (2014), "The Indicators of the Economic Burdens of Environmental Policy Design: Results from the OECD Questionnaire", OECD Economics Department Working Papers, No. 1178, OECD Publishing.

Le, T., G. Scobie and J. Gibson (2009), "Are Kiwis Saving Enough for Retirement: Evidence from SoFIE”, New Zealand Economic Papers, Vol. 43. No. 1.

Maré, D. and S. Stillman (2009) "The Impact of Immigration on the Labour Market Outcomes of New Zealanders", Department of Labour, Commissioned by the Economic Impacts of Immigration Research Programme of the Department of Labour, Wellington.

Massey University (2015), Home Affordability Report, March.

McDonald, C. (2013), "Migration and the Housing Market", Reserve Bank of New Zealand Analytical Note Series 2013/10, December.

Meehan, L. (2014), "Structural Change and New Zealand's Productivity Performance”, New Zealand Productivity Commission, Working Paper 2014/4, June.

Ministry of Business, Innovation and Employment (MBIE) (2013), Housing Affordability: Residential Land Available in Auckland, Wellington, February.

Ministry of Business, Innovation and Employment (MBIE) (2014a), Quarterly Canterbury Job-Matching Report, Wellington, December.

Ministry of Business, Innovation and Employment (MBIE) (2014b), Quarterly Labour Market Report, Wellington, August.

National Infrastructure Unit (NIU) (2015), Infrastructure Evidence Base 2015 Refresh: Transport Sector, Wellington, March.

New Zealand Institute of Economic Research (NZIER) (2014), "The Home Affordability Challenge”, NZIER Public Discussion Paper 2014/4, July.

New Zealand Productivity Commission (2012), Housing Affordability Inquiry, March.

New Zealand Productivity Commission (2014a), Boosting Productivity in the Services Sector, May.

New Zealand Productivity Commission (2014b), Using Land for Housing Issues Paper, November. 


\section{ECO/WKP(2015)65}

New Zealand Treasury (2014a), Half Year Economic and Fiscal Update 2014, Wellington.

New Zealand Treasury (2014b), Holding On and Letting Go, Wellington.

OECD (2007), Infrastructure to 2030 (Volume 2): Mapping Policy for Electricity, Water and Transport, OECD Publishing.

OECD (2008), Public-Private Partnerships: In Pursuit of Risk Sharing and Value for Money, OECD Publishing.

OECD (2010), Implementing Congestion Charging, OECD Publishing.

OECD (2011), OECD Economic Surveys: New Zealand 2011, OECD Publishing.

OECD (2013), OECD Economic Surveys: New Zealand 2013, OECD Publishing

OECD (2014a), Education at a Glance 2014: OECD Indicators, OECD Publishing.

OECD (2014b), OECD Health Statistics 2014: How does New Zealand Compare?, OECD Publishing.

OECD (2014c), OECD Pensions Outlook 2014, OECD Publishing.

OECD (2014d), Recruiting Immigrant Workers: New Zealand 2014, OECD Publishing

OECD (2015a), Water and Cities: Ensuring Sustainable Futures, OECD Publishing.

OECD (2015b), OECD Development Co-operation Peer Reviews: New Zealand 2015, forthcoming.

Petrie, M. (2013), Fiscal Transparency, Transparency International New Zealand.

Poterba, J., S. Venti and D. Wise (1995), “Do 401(k) Contributions Crowd Out Other Personal Saving?", Journal of Public Economics, Vol. 58, September.

Poterba, J., S. Venti and D. Wise (1996), "How Retirement Programs Increase Savings", Journal of Economic Perspectives, Vol. 10, No. 4.

Price, G. (2014), "How Has the LVR Restriction Affected the Housing Market: A Counterfactual Analysis", Reserve Bank of New Zealand Analytical Note Series 2014/03, May.

Price, R., I. Joumard, C. André and M. Minegishi (2008), "Strategies for Countries with Favourable Fiscal Positions", OECD Economics Department Working Paper, No. 655, OECD Publishing.

Reserve Bank of New Zealand (RBNZ) (2013), Monetary Policy Statement, September.

Reserve Bank of New Zealand (RBNZ) (2015), "The Bank Consulting on Property Investor Loans" http://www.rbnz.govt.nz/news/2015/bank-consulting-on-property-investor-loans-1.html, 5 March 2015.

Rogers, L. (2014), “An A to Z of Loan-to-Value Ratio (LVR) Restrictions”, Reserve Bank of New Zealand: Bulletin, March, Vol. 77. No. 1. 
de Serres, A., N. Yashiro and H. Boulhol (2014), "An International Perspective on the New Zealand Productivity Paradox", New Zealand Productivity Commission Working Paper 2014/1, April.

Statistics New Zealand (2014), Business Operations Survey: 2013, Wellington.

Statistics New Zealand (2015), Business Operations Survey: 2014, Wellington.

Ter-Minassian, T. (2014), External Review of the Treasury's Fiscal Policy Advice, Washington.

TomTom (2015), TomTom Traffic Index, http://www.tomtom.com/en_nz/trafficindex/, 4 May 2015.

Wallis, I and D. Lupton (2013). "The Cost of Congestion Reappraised", NZ Transport Agency Research Report 489, February.

World Economic Forum (2014), The Global Competitiveness Report: 2014-2015, Geneva.

Zuccollo, J., S. Maani, B. Kaye-Blake and L. Zeng (2013), "Private Returns to Tertiary Education: How Does New Zealand Compare", New Zealand Treasury Working Paper 13/10, July. 